\title{
Megaspore assemblages from the Åre Formation (Rhaetian-Pliensbachian) offshore mid-Norway, and their value as field and regional stratigraphical markers
}

\author{
PETER H. MORRIS ${ }^{1, *}$, ALEX CULLUM ${ }^{2}$, MARTIN A. PEARCE ${ }^{3}$ \& DAVID J. BATTEN ${ }^{4}$ \\ ${ }^{1}$ Microstrat Services Southcott, Buckland Brewer, Bideford, Devon EX39 5LU, UK \\ ${ }^{2}$ StatoilHydro ASA, N-4035 Stavanger, Norway \\ ${ }^{3}$ StatoilHydro ASA, N-5020 Bergen, Norway \\ ${ }^{4}$ School of Earth, Atmospheric and Environmental Sciences, University of Manchester, Oxford Road, Manchester M13 9PL, UK \\ *Corresponding author (e-mail: MicrostratUK@aol.com)
}

\begin{abstract}
A megaspore biozonation of the non-marine Åre Formation is proposed, based on a micropalaeontological analysis of key Haltenbanken area wells (Block 6608/11). The lower part of the Åre Formation is divisible into Banksisporites pinguis, Nathorstisporites hopliticus and Horstisporites areolatus zones, and subzones, occupying the Rhaetian-Hettangian interval. In the upper Åre Formation a marked turnover of megaspore assemblages is evident, with the appearance of several species of Trileites and the mesofossil Kuqaia quadrata. On this basis, the biozonation is extended into the Sinemurian-Pliensbachian, with the recognition of the Kuqaia quadrata Zone and subzones. Reference to selected wells in the Urd Field (Block 6608/10) and further south demonstrates that these biozones correlate across the northern Haltenbanken region. Biozonal boundaries are calibrated with miospore/microplankton markers where possible, to provide a robust bio-chronostratigraphical framework with which to evaluate the stratigraphy of the Åre Formation and its reservoir units. Comparison with published European biostratigraphical data shows that a similar megaspore succession exists through the Rhaeto-Liassic interval, with shifts in megaspore composition occurring within the same time intervals. On this evidence it is suggested that the megaspore biozones identified are regionally extensive and may reflect palaeoclimatic controls on the distribution of the megaspore-producing plants. It is concluded that megaspores are a stratigraphically important microfossil group, which should be utilized routinely in Upper Triassic-Jurassic oil field and regional biostratigraphical studies. J. Micropalaeontol. 28(2): 161-181, November 2009.
\end{abstract}

KEYWORDS: megaspores, micropalaeontology, Upper Triassic-Jurassic, Are Formation, mid-Norway

\section{INTRODUCTION}

Atlantic margin, Upper Triassic-Lower Jurassic sediments include reservoir units within the Åre Formation that form several major oil fields on the Heidrun-Norne trend (Fig. 1). Until recently, biostratigraphical evaluation of the Åre Formation in the Haltenbanken region was based primarily on palynological analysis, but the predominance of morphologically diverse, long-ranging miospores prevented reliable biozonation of reservoir units (see below). During such phases of evaluation, megaspores were generally excluded from palynological preparations because of their comparatively large size; they are usually removed along with plant debris through 'swirling' and filtering. Moreover, at least $100 \mathrm{~g}$ of sample is required to extract significant numbers of megaspores, compared with about $5 \mathrm{~g}$ or $10 \mathrm{~g}$ for miospores (e.g. see Batten \& Koppelhus, 1993).

Although it has long been established that megaspores can occur abundantly in conventional micropalaeontological preparations of non-marine sediments (e.g. Keuper: Wicher, 1957), in which the minimum sieve size is $c .63 \mu \mathrm{m}$, the potential for megaspore extraction has generally been overlooked or ignored. Consequently, micropalaeontological analyses of non-marine sediments, including those of the Åre Formation, have not normally been undertaken during routine well analyses. Furthermore, since megaspore systematics has been perceived by many micropalaeontologists to fall within the domains of palaeobotany and palynology, encounters with megaspores, even in marginal marine and marine sections (e.g. the Båt and Fangst groups), has often led to assemblages being unspeciated. As a result, the stratigraphical value of offshore, Upper Triassic-
Jurassic megaspores has remained largely unevaluated, especially in the North Sea and Atlantic margin regions.

During routine evaluation of Norwegian well 6608/11-4, (Figs 1a, b), micropalaeontological analysis of the marine Cretaceous section was extended downwards into the Lower Jurassic Åre Formation and Upper Triassic 'Grey' and 'Red' beds (Terminal Depth: Fig. 2). Analysis of cuttings and cores from this succession, which comprises $650 \mathrm{~m}$ of mainly nonmarine claystones, coals and sandstones, revealed a distinct succession of megaspore floras (Fig. 3). Following this first encounter, the biostratigraphical potential of the megaspores was further evaluated by StatoilHydro through the analysis of several exploration and production wells in the Urd Field area (Figs 1b, c) and further south on the Halten Terrace and Trondelag Platform (Fig. 1b).

The main objective of this paper is to present the biostratigraphical data from this initial phase of research with reference to selected wells from the Haltenbanken area. A megaspore/ mesofossil biozonal scheme is proposed for the latter region, which, by comparison with previously published data, is also shown to have regional application.

\section{REGIONAL GEOLOGICAL SETTING AND LITHOSTRATIGRAPHY}

Wells examined for the present study penetrated the Åre Formation at the northern end of the Nordland Ridge (6608/10 and 6608/11 blocks), the Halten Terrace (6607/12-3) and further east, on the Trondelag Platform (6508/5-1). Their locations are shown in relation to the main structural elements in Figure $1 \mathrm{~b}$. 

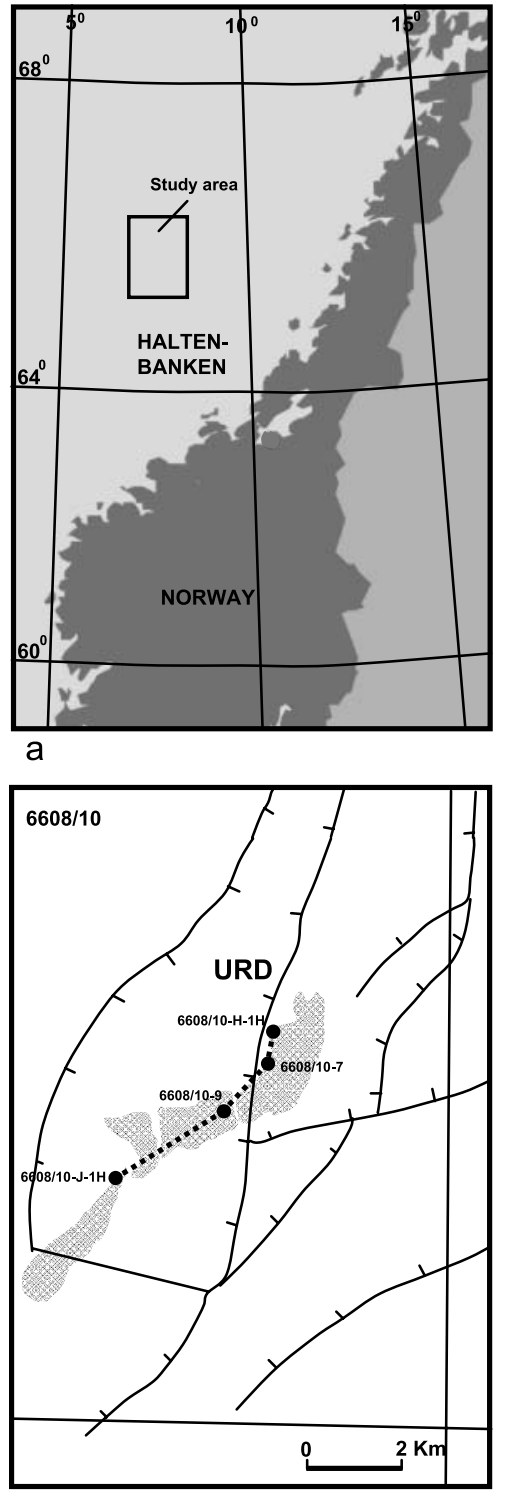

C

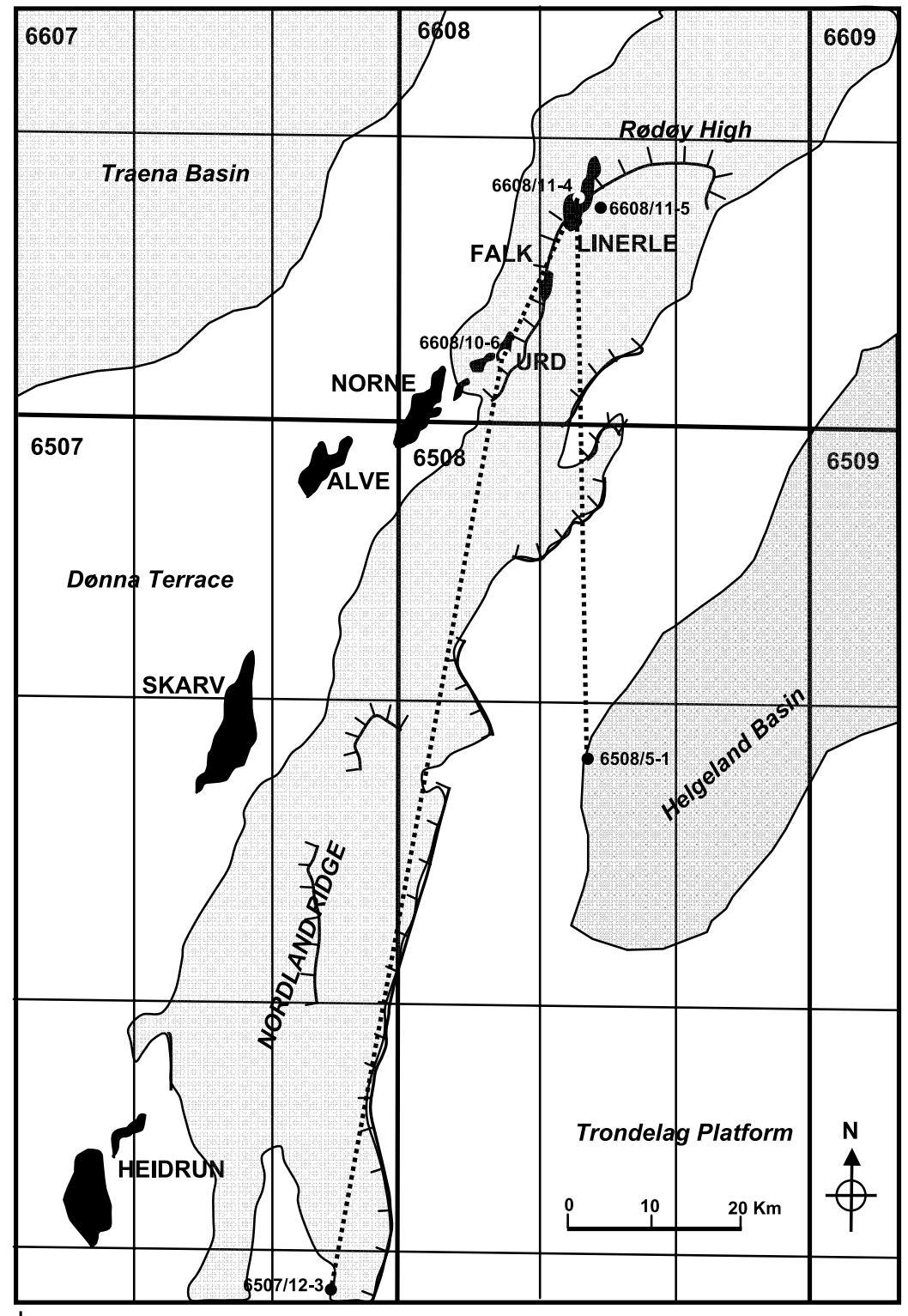

b

Fig. 1. (a) Location map of study area, offshore mid-Norway. (b) Details of study area showing location of oil fields and study wells (black dots) in relation to the main structural elements (after Dalland et al., 1988); line of well correlation (Fig. 7) indicated by dashed line. (c) Location of study wells, Urd Field, and line of correlation (Fig. 8).

The Åre Formation comprises the lowest unit of the Båt Group, which succeeds the transitional facies of the continental 'Red Beds' and 'Grey Beds' (Fig. 2: see Dalland et al., 1988 for lithostratigraphical definitions). The lower Åre Formation was deposited during the Rhaetian-Hettangian at a time of relative tectonic quiescence, accumulating in established Permo-Triassic rifted basins (Ziegler, 1990; Blystad et al., 1995). Non-marine, fluvio-deltaic and possibly lacustrine facies were extensively developed during this period, with deposition of organic matter leading to the formation of coals at a number of horizons (Dalland et al., 1988; Pedersen et al., 1989). During the Sinemurian-Pliensbachian the development of NNE-SSWtrending growth faults led to higher clastic input, with the development of extensive sandstones, which form the main reservoirs in the upper Åre Formation (Dalland et al., 1988; Pedersen et al., 1989). Whereas deposition of the upper Åre Formation is considered to have been in marginal marine conditions, there is a general absence of marine microfaunas and palynofloras, compared to younger Jurassic units (e.g. the Not and Melke formations), but there is a significant shift in the composition of megaspore/mesofossil assemblages (see below).

The general lithostratigraphical nomenclature used in this study follows Dalland et al. (1988), and this is shown in relation to their chronostratigraphical assignments in Figure 2. As these authors pointed out, however, based on log character alone, problems arise in defining the upper and lower boundaries of the Åre Formation, especially the latter where the boundary with the underlying 'Grey Beds' is transitional. 


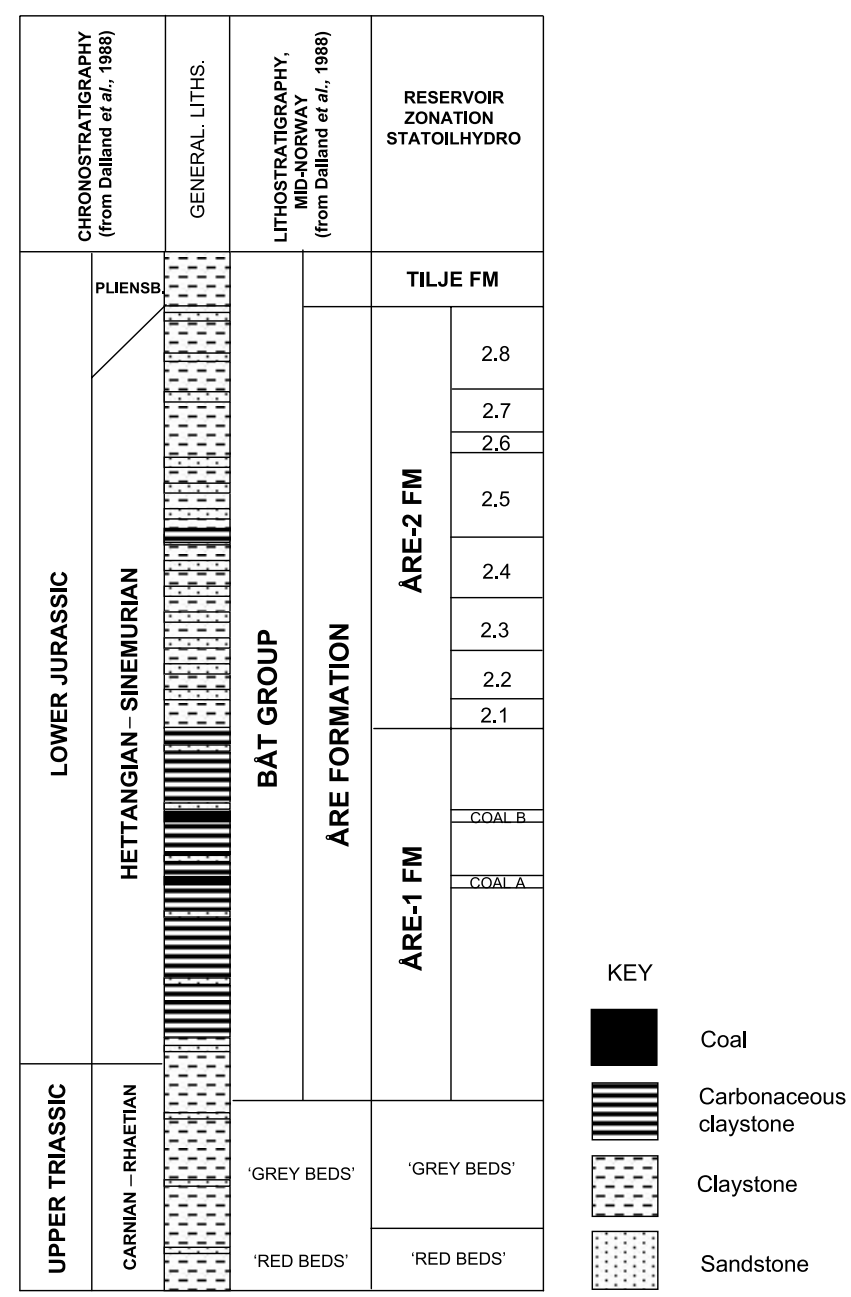

Fig. 2. Chronostratigraphy and lithostratigraphy of the Åre Formation, mid-Norway (after Dalland et al., 1988), and reservoir zonation used in this study (StatoilHydro unpublished).

Subdivision of the Åre Formation has been undertaken informally by operators in a number of field areas, based primarily on log character. In the Norne Field area (Block 6608/10), StatoilHydro divides the unit into Åre-1 and Åre-2, with the latter further subdivided into eight reservoir zones (2.1-2.8), which are shown schematically in Figure 2.

\section{MATERIAL AND METHODS}

During initial routine well evaluation of 6608/11-4, the extraction of megaspores involved conventional micropalaeontological processing methods, including soaking of disaggregated core chips and washed cuttings samples (c. $120 \mathrm{~g}$.) in $200 \mathrm{ml}$ of $10 \%$ $\mathrm{w} / \mathrm{v}$ hydrogen peroxide. Owing to the differences in density between plant material (including megaspores) and mineral grains, a technique was subsequently developed to 'pan-out' the former during the wet-sieving phase in order to concentrate megaspores in residues with high sand content. This technique was particularly suitable for the reservoir sections of the Àre Formation in the Urd Field where the thermal maturity is generally low. Minor corrosion and fragmentation of megaspores occurred frequently using these extraction methods owing to the oxidizing effects of hydrogen peroxide and mechanical abrasion, but this normally did not significantly impair species identification.

Since the initial recovery of megaspores in 6608/11-4, more than 20 wells have been evaluated for megaspores in the Haltenbanken region. In these studies, conventional core was sampled at intervals of less than $1 \mathrm{~m}$, and cuttings at less than $6 \mathrm{~m}$, where possible. Sampling points in individual wells were closely tied to wireline logs to focus on low density, carbonaceous claystones.

Analysis of picked samples involved quantitative counts of megaspores and other mesofossils, and semi-quantitative counts of plant material, which was classified informally as: (a) miscellaneous cuticles and stem and leaf fragments that are noncarbonized and generally translucent; (b) indeterminate filaments, which are often associated with megaspores; (c) sporangial fragments; (d) fusain, used informally to include all carbonized plant material. These components are not, however, considered in this paper because little biostratigraphical significance could be attached to their distribution, although a positive correlation exists between the occurrence of megaspores and cuticle, filament and sporangial frequency.

Not all of the megaspores were identifiable because of poor preservation. These are plotted on Figures 3-5 as 'Indet. megaspore-like bodies (casts)' and 'Indet. megaspore spp.', the former comprising diagenetic (commonly sideritic) infills of megaspores, their exines having been lost as a result of abrasion through reworking and, in some cases, possibly during laboratory processing. Also recorded were indeterminate miospore species which were observed within the matrix of sediment pieces in coarser sieved residues, but these are not discussed because they are beyond the scope of this paper.

\section{MEGASPORES RECOVERED}

\section{Classification and description}

Koppelhus \& Batten (1992) noted that the formal system of megaspore taxonomy proposed by Potonié $(1956,1958,1960)$ is difficult to apply and, owing to its hierarchical nature, may separate genera of similar appearance and group together others that are clearly distinct. Hence, the megaspores recorded herein are grouped generically according to overall morphology and degree of exine sculpture and complexity. Since the main aim of this paper is biostratigraphical rather than taxonomic, only brief descriptions are provided, with just the original species citation presented. Bibliographical details for all records of species described before 1989, and the ages reported for these occurrences, are given in Batten \& Kovach (1990); their ranges, plotted in Kovach \& Batten (1989), are based on these data. References to more recent records are cited below where required.

The descriptive terminology used is standard. The dimensions of specimens are given as the maximum diameter of the megaspore body, excluding sculptural elements. The spore wall (exine) is a non-rigid substance that is prone to deformation, shrinkage and fracturing; hence, the measurements made are only approximate. Colour is described for dry specimens only. This varies according to the thickness, structure and degree of thermal alteration of the exine; as a result, although worth recording, it has little taxonomic significance. 
P. H. Morris et al.

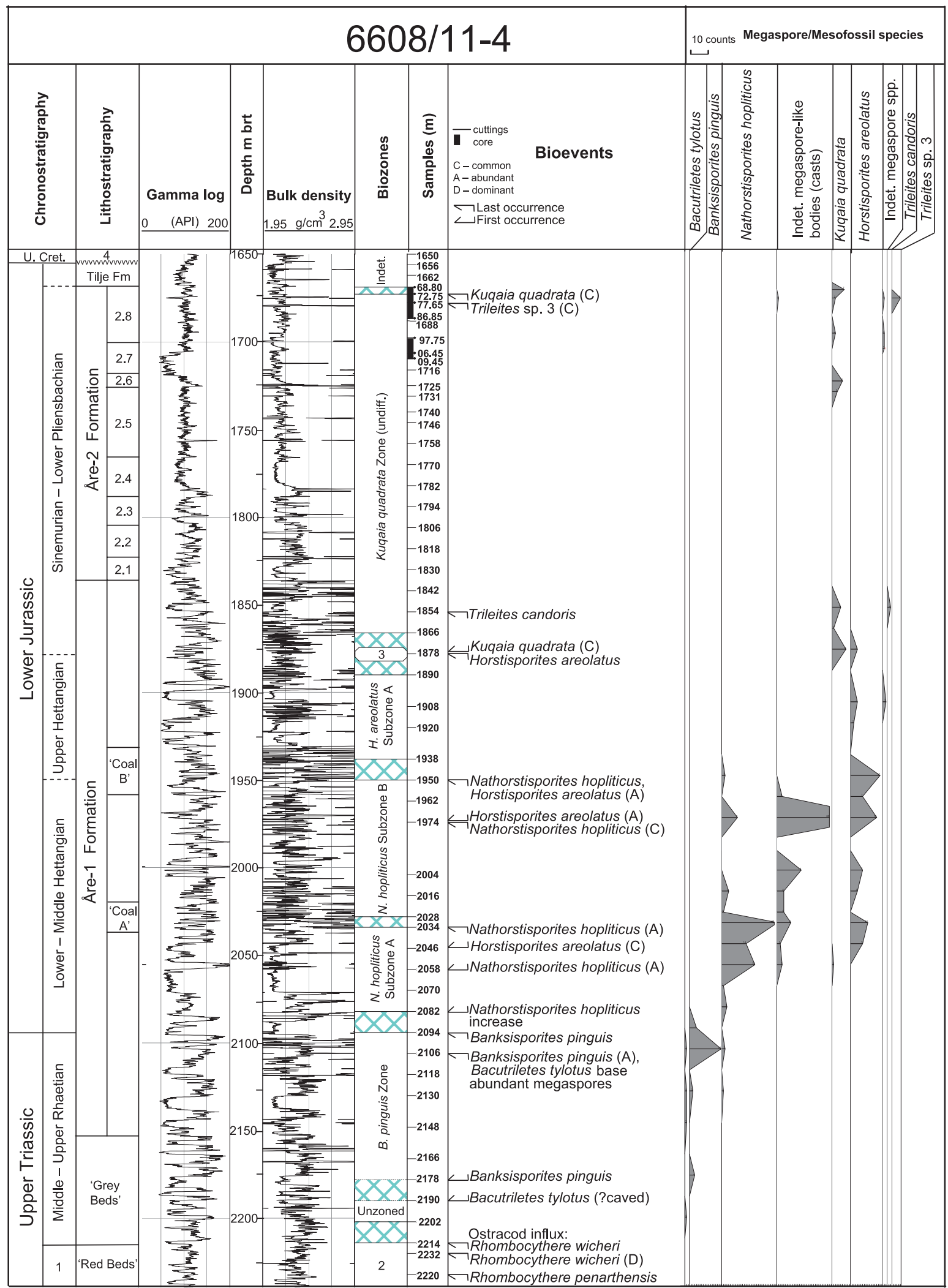

1. U. Norian - L. Rhaetian 3. H. areolatus Subzone B

2. R. penarthensis Zone 4. Springar Fm

Fig. 3. Chronostratigraphy, lithostratigraphy and wireline logs through the Åre Formation of well 6608/11-4, showing megaspore distribution, key bioevents and biozonation. 


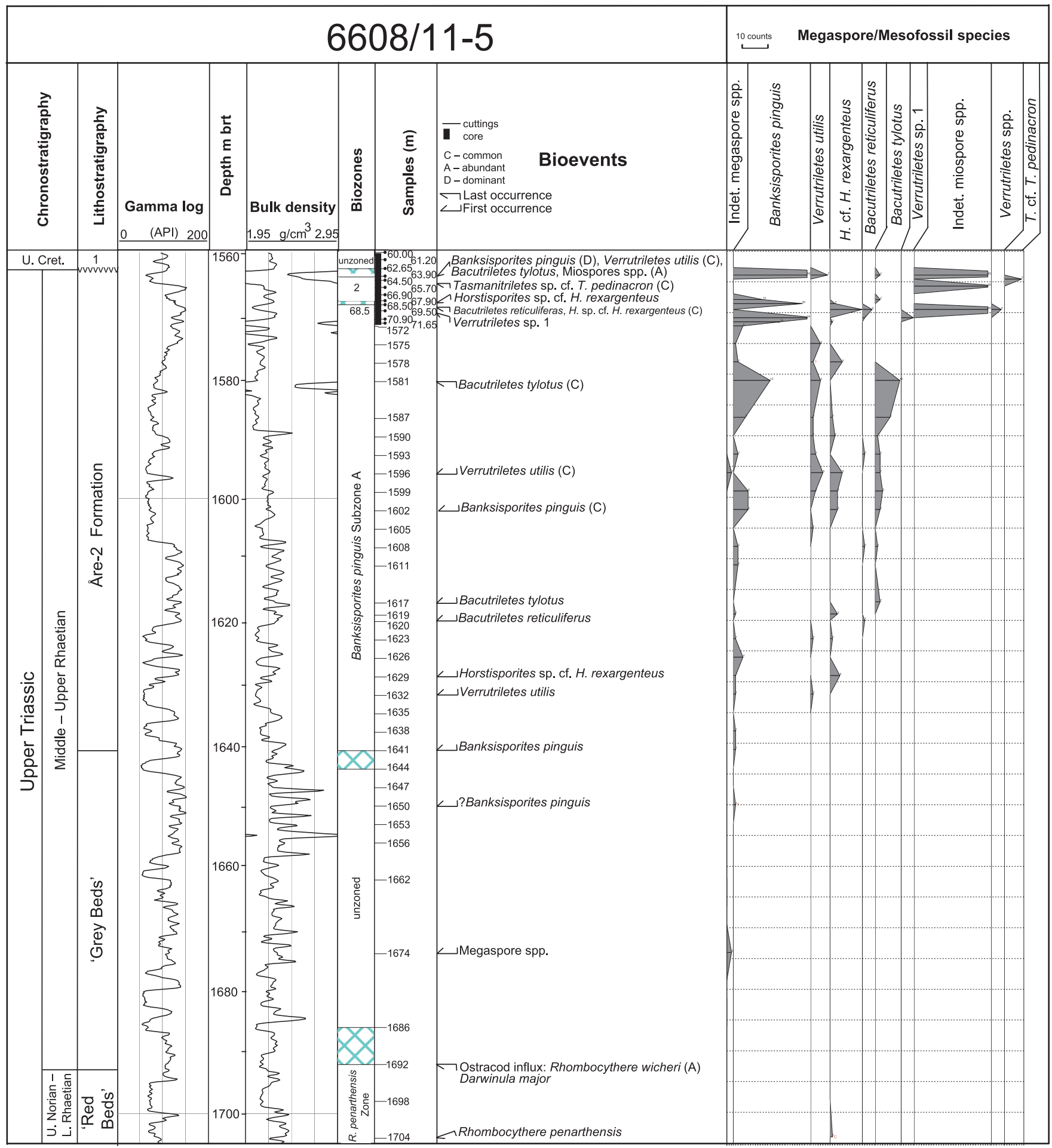

1. Springar Fm

2. Banksisporites pinguis Subzone B

Fig. 4. Chronostratigraphy, lithostratigraphy and wireline logs through the Åre Formation of well 6608/11-5, showing megaspore distribution, key bioevents and biozonation.

All of the specimens illustrated on Plates 1-3 were deposited in the collections of the British Geological Survey, Keyworth, Nottingham (catalogue numbers prefixed by MPK). They were photographed in reflected light using a Bresser, 1.3 megapixel
'Microcular' digital camera, in combination with a stereomicroscope. In conventional photomicroscopy of uncompressed megaspores and other microfossils the amount of detail in focus is limited by the depth of the focal plane: this reduces with 


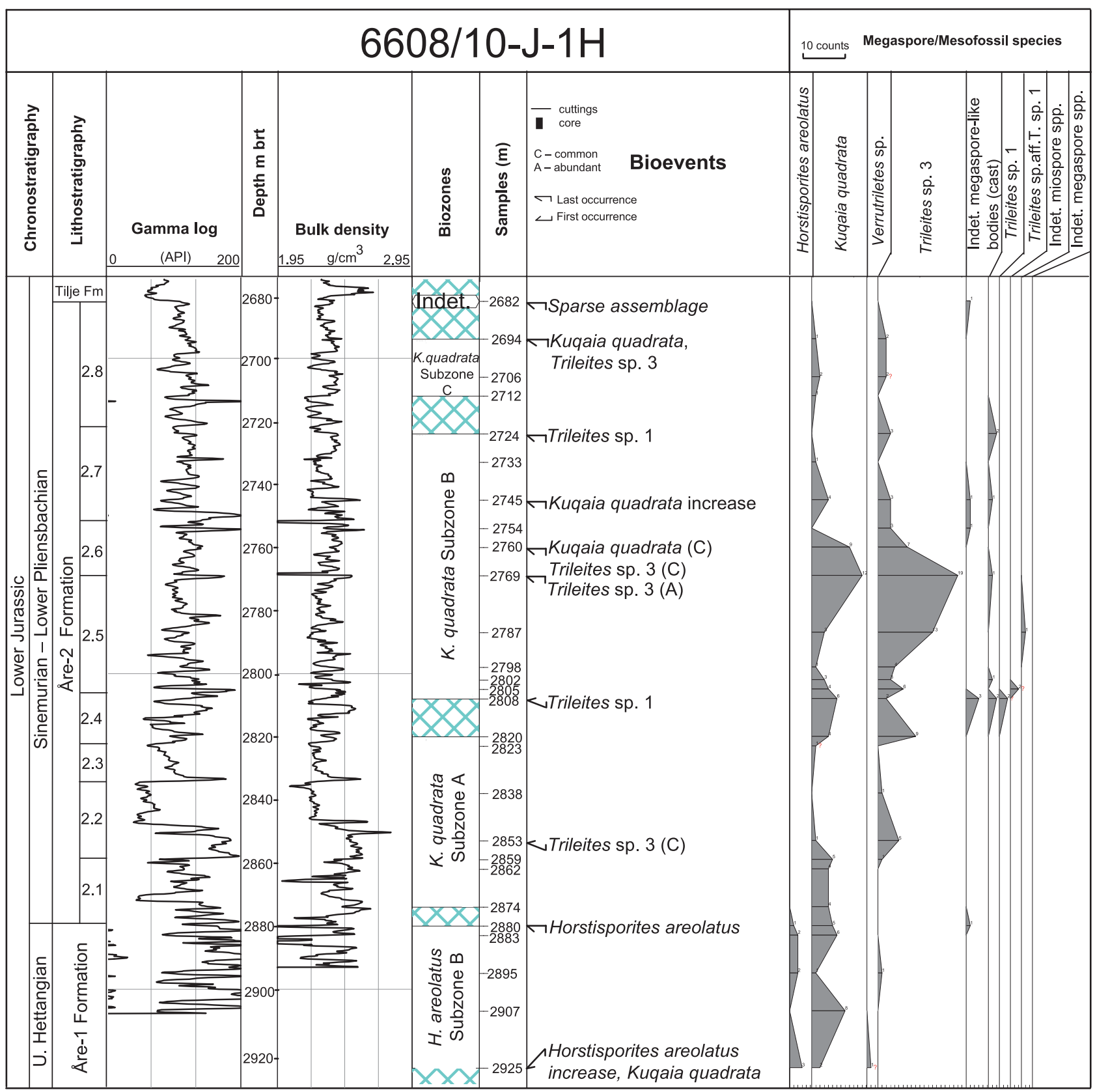

Fig. 5. Chronostratigraphy, lithostratigraphy and wireline logs through the Åre Formation of well 6608/10-J-1H, Urd Field, showing megaspore distribution, key bioevents and biozonation.

increasing magnification so that much of the image in any single photograph is blurred. This optical limitation was overcome here through the use of 'Helicon Focus Tm' imaging software, which allows several focal-plane images (taken in stages through the field of focus) to be combined digitally into one. All of the photomicrographs in this paper here were handled in this way.

\section{Systematic descriptions}

The descriptions below are based on observations of specimens examined only under a binocular microscope: no scanning electron microscopy was undertaken. Mineral grains are attached to some specimens because the assemblages were not 'cleaned' by immersion in hydrofluoric acid. Several taxa were identified in open nomenclature including those attributed to Trileites: formalization of these species is intended in a later publication.

Genus Trileites Erdtman, 1947 ex Potonié, 1956

Trileites candoris Marcinkiewicz, 1960 (Pl. 1, fig. 6)

Material. Eight specimens recorded from wells 6608/11-4, 6608/ 10-6 and 6608/10-7 (Not and Melke formations). 

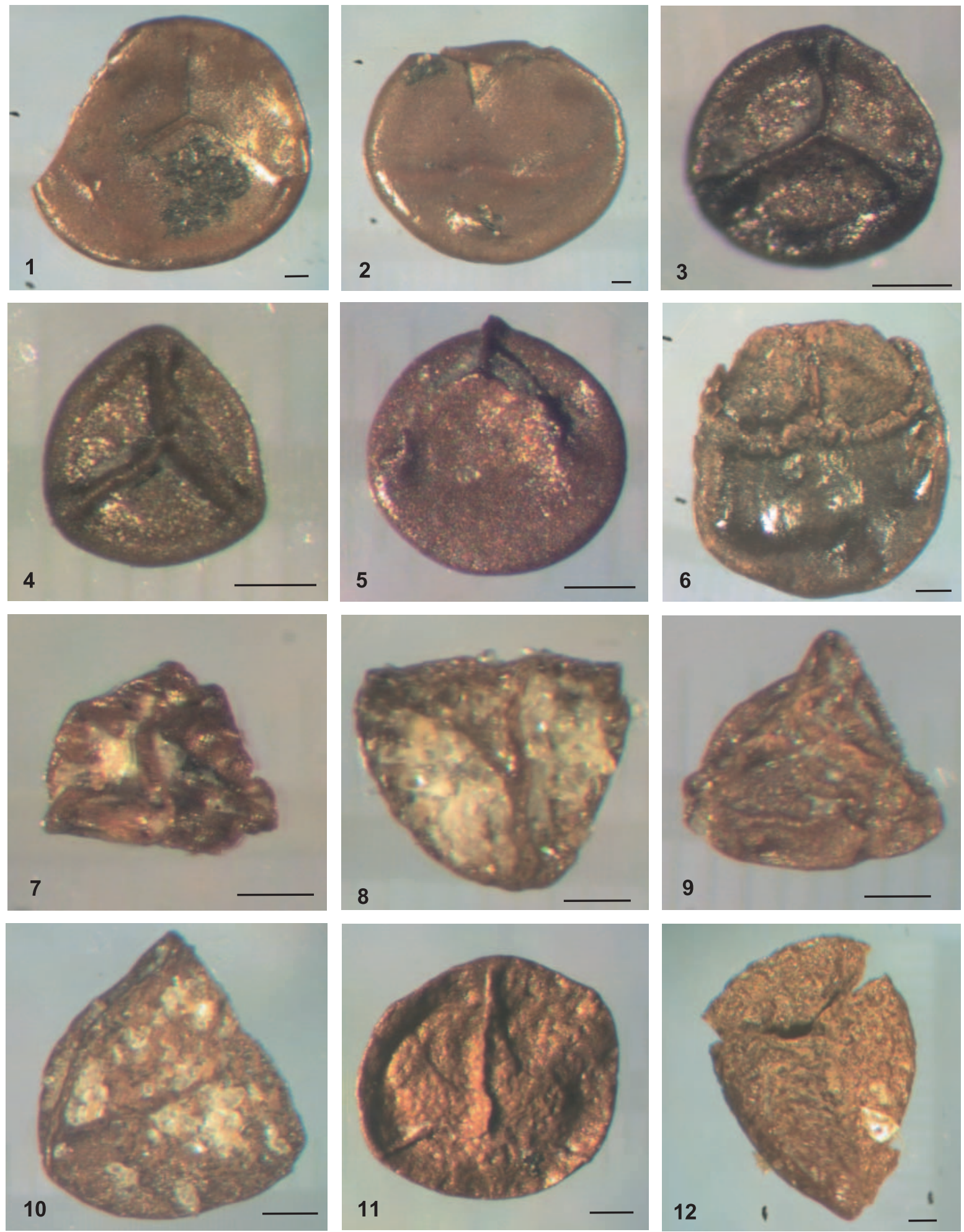

Explanation of Plate 1.

figs 1, 2. Tasmanitriletes sp. cf. T. pedinacron (Harris, 1935), 6608/11-5, $1564.50 \mathrm{~m}$; proximal and laterally compressed specimens, respectively; MPK13750, 13751. figs 3-5. Banksisporites pinguis (Harris, 1935), 6508/5-1, $2385 \mathrm{~m}$, compressed specimens: 3, 4, proximal and 5, oblique dorsal views; MPK13752-13754. fig. 6. Trileites candoris Marcinkiewicz, 1960, 6608/11-4, 1854 m; laterally compressed specimen; MPK13755. figs 7, 8. Trileites sp. 1; specimens compressed in proximal view, 6608/10-J-1H, $2808 \mathrm{~m}$ and 6608/10-9, $2251 \mathrm{~m}$, respectively; MPK13756, 13757. figs 9, 10. Trileites sp. 2; specimens compressed in proximal and oblique proximal views, 6608/10-H-1H, $3048 \mathrm{~m}$ and 6608/10-7, 2096.70 m, respectively; MPK13758, 13759. figs 11, 12. Trileites sp. 3; specimens from 6507/6-3, $1583 \mathrm{~m}$ and 6608/11-4, $1672.65 \mathrm{~m}$ compressed in proximal view and relatively uncompressed but partially fragmented, respectively; MPK13760, 13761. Scale bars represent $100 \mu \mathrm{m}$. 
Description. A large trilete megaspore, circular in equatorial outline, equatorial diameter $700-800 \mu \mathrm{m}$; triradiate ridges c. $40 \mu \mathrm{m}$ high and $30-40 \mu \mathrm{m}$ broad extend to $0.5-0.6$ radius of spore. Curvaturae very prominent, forming raised, crenulated ridges $c$. 50-60 $\mu \mathrm{m}$ broad that curve up at points of contact with triradiate ridge (Pl. 1, fig. 6). Exine $10-15 \mu \mathrm{m}$ thick, smooth, lustrous, medium orange-brown to dark brown.

Stratigraphic occurrence. Recorded from the uppermost Åre-1 Formation to basal Åre-2 Formation (Kuqaia quadrata Zone, Subzone A) in 6608/11-4 and 6608/11-5. It is also present in megaspore assemblages from the Not and Melke formations (Aalenian-Bajocian) in 6608/10-7. Originally reported from Toarcian deposits, this species was recorded (as Trileites turbanaeformis; see Marcinkiewicz, 1981 for synonymy) from throughout the Lower Jurassic (Kovach \& Batten, 1989; Batten \& Kovach, 1990; Koppelhus \& Batten, 1992).

Remarks. Our material compares closely with the holotype of Marcinkiewicz (1960) from the upper Lias (Toarcian) in Poland. It is also similar in size and gross morphology to Margaritatisporites regalis Marcinkiewicz, 1962, but lacks granules between the triradiate ridge, characters that were later considered by Marcinkiewicz (1981) to be included within the circumscription of Trileites candoris.

\section{Trileites sp. 1}

(P1. 1, figs 7, 8)

Material. Twenty-one specimens from several Urd Field wells.

Description. A small to medium-sized trilete megaspore, subtriangular-triangular in equatorial outline, $200-400 \mu \mathrm{m}$ in equatorial diameter; pronounced triradiate ridges $15-20 \mu \mathrm{m}$ broad extend to, or almost to, equator producing a highly angular, trigonal-shaped spore. Linear compaction folds or undulations often present between, and extend away from, ridges. Exine $10-15 \mu \mathrm{m}$ thick, commonly modified by impressions of minerals from the associated sediment; in well-preserved specimens it appears smooth, semi-lustrous and light-medium orange-brown.

Stratigraphic occurrence. Recorded from the upper Åre-2 Formation in several wells where it is the index taxon for Subzone B of the Kuqaia quadrata Zone.

Remarks. The trigonal profile of this taxon distinguishes it from other published species of Trileites. It is similar in gross morphology to Trileites sp. 2 (described below), but lacks curvaturae. It has been assigned previously to Trileites sp. 5 in unpublished StatoilHydro reports.

Trileites sp. 2

(P1. 1, figs 9, 10)

Material. Fourteen specimens from several Urd Field wells.

Description. A medium-sized trilete megaspore, subtriangular-triangular in equatorial outline, $350-500 \mu \mathrm{m}$ in equatorial diameter. Pronounced triradiate ridges $15-20 \mu \mathrm{m}$ broad, extend to $0.7-0.9$ radius, producing a highly angular, trigonal-shaped spore. Distinct curvaturae consist of prominent raised ridges c. $20 \mu \mathrm{m}$ broad (Pl. 1, fig. 9). Exine 10-15 $\mu \mathrm{m}$ thick, often crumpled and folded as a result of compaction, and commonly showing impressions of mineral grains from the surrounding matrix; in well-preserved specimens it appears smooth, semilustrous, light-medium orange-brown.

Stratigraphic occurrence. Recorded from the lower Åre-2 Formation in several wells where it is restricted to the Kuqaia quadrata Zone, Subzone A.

Remarks. This species is similar in gross morphology to Trileites sp. 1, but differs in possessing distinct curvaturae. It has been assigned previously to Trileites sp. 6 in unpublished StatoilHydro reports.

Trileites sp. 3

(Pl. 1, figs 11, 12)

Material. Two hundred and thirty-four specimens from several Urd and Haltenbanken exploration wells.

Description. A medium-sized to large trilete megaspore, subtriangular in equatorial outline, $400-900 \mu \mathrm{m}$ in equatorial diameter. Slightly raised triradiate ridges $15-20 \mu \mathrm{m}$ broad extend to $0.7-0.8$ radius of spore. Weakly developed curvaturae consisting of narrow, raised ridges $15 \mu \mathrm{m}$ broad in equatorially compressed specimens (Pl. 1, fig. 11). Exine $<10 \mu \mathrm{m}$ thick, invariably showing indentations of mineral grains from surrounding matrix and compaction undulations and folds; wall also prone to breaking up into triangular fragments during laboratory processing (e.g. Pl. 1, fig. 12). In well-preserved specimens it appears smooth, semi-lustrous, medium-dark orange-brown.

Stratigraphic occurrence. Recorded throughout the Åre-2 Formation in several wells, becoming common through the Åre 2.5-2.8 units, Kuqaia quadrata Zone, Subzone B.

Remarks. The generally poor preservation of this spore makes comparison with published species difficult: certain forms of Trileites from the upper Lias (Toarcian) may, however, be conspecific (e.g. Trileites sp. in Marcinkiewicz, 1960, pl. 2, figs 3, 4). It has been assigned previously to Trileites sp. 7 in unpublished StatoilHydro reports.

\section{Genus Tasmanitriletes Jux \& Kempf, 1971}

Tasmanitriletes cf. T. pedinacron (Harris, 1935) Jux \& Kempf, 1971

(P1. 1, figs 1, 2)

Material. Eight specimens from well 6608/11-5.

Description. A large trilete megaspore, circular in equatorial outline, $750-800 \mu \mathrm{m}$ in equatorial diameter; all specimens flattened. Laesurae straight, extending from $0.5-0.9$ radius of spore, bordered by low ridges $5-10 \mu \mathrm{m}$ wide, often gaping as a result of compaction (Pl. 1, fig. 2). Curvaturae present as low ridges 

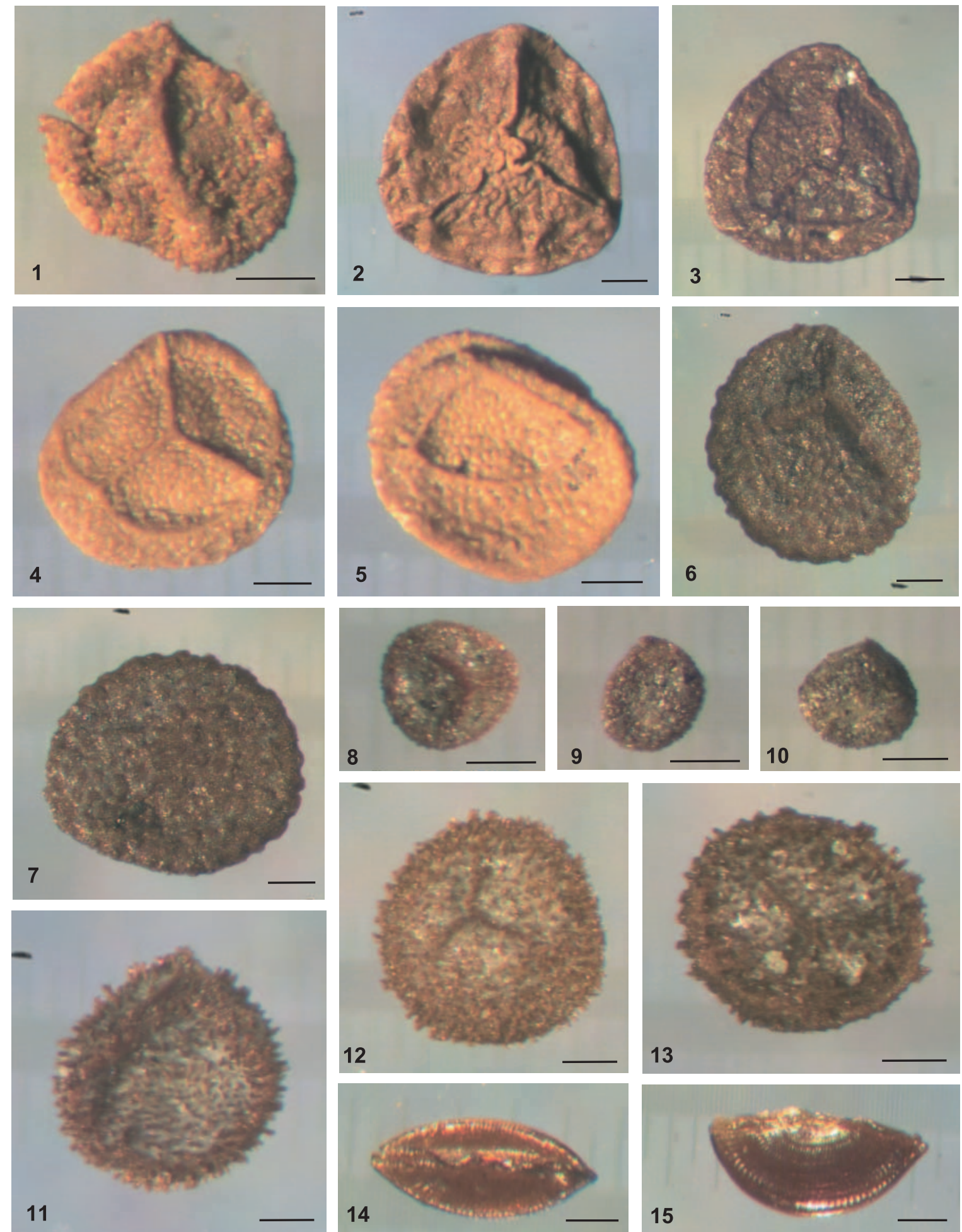

Explanation of Plate 2.

fig 1. Horstisporites sp. cf. H. planatus Marcinkiewicz, 1960; 6608/11-6, 1636 m; oblique proximal view; MPK13762. figs 2, 3. Verrutriletes franconicus Jung, 1960; specimens from 6507/6-3, $1574 \mathrm{~m}$ and $1550 \mathrm{~m}$, respectively, compressed in proximal view; MPK13763, 13764. figs 4, 5. Verrutriletes utilis (Marcinkiewicz, 1962); compressed specimens from 6608/11-5, $1590 \mathrm{~m}$ and 6608/11-5, $1587 \mathrm{~m}$ in proximal and lateral views, respectively; MPK13765, 13766. figs 6, 7. Verrutriletes sp. 1; compressed specimen from 508/5-1, $2385 \mathrm{~m}$ in proximal and distal views, respectively; MPK13767. figs 8-10. Bacutriletes reticuliferus Bertelsen \& Michelson, 1970, 6608/11-5, 1569.50 m; partly compressed specimens in proximal, lateral and oblique proximal views; MPK13768-13770. figs 11-13. Bacutriletes tylotus (Harris, 1935), partly compressed specimens in (11, from 6608/11-5, 1608 m) lateral and (12, 13, from 6608/11-5, $1602 \mathrm{~m}$ ) proximal views, the last of these showing coarse bacula; MPK13771-13773. figs 14, 15. Kuqaia quadrata Li Wen-ben, 1993, 6608/10-7, $2030.70 \mathrm{~m}$; dorsal and compressed lateral views; MPK13774, 13775. Scale bars represent $100 \mu \mathrm{m}$. 
c. $50 \mu \mathrm{m}$ broad. Exine c. $30 \mu \mathrm{m}$ thick, smooth, lustrous, medium-dark brown.

Stratigraphic occurrence. Recorded in two samples only from 6608/11-5, upper Åre-1 Formation (Banksisporites pinguis Zone, Subzone B).

Remarks. Our spores are similar in size to the two specimens from East Greenland on which Harris (1935) based his species Triletes pedinacron, now Tasmanitriletes pedinacron, as indicated above, but the species he described from the Yorkshire Jurassic (Harris, 1961) as Triletes murrayi, now Trileites murrayi (Harris, 1961) Marcinkiewicz, 1971, appears to be more closely comparable to the morphology of our material. On the other hand, almost all of the records of this species are from younger strata than we have investigated in this paper (for an exception, see Wierer, 1997). Hence, for the time being, we prefer to compare our species to Tasmanitriletes pedinacron rather than to Triletes murrayi.

Genus Banksisporites Dettmann, 1961 emend. Banerji et al., 1978

Banksisporites pinguis (Harris, 1935) Dettmann, 1961 (Pl. 1, figs 3-5)

Material. Over 400 specimens from several Haltenbanken wells.

Description. A medium-sized trilete megaspore, equatorial diameter $250-450 \mu \mathrm{m}$, small specimens subtriangular in equatorial outline, larger specimens more circular. Laesurae extend to $0.7-0.9$ radius of spore, raised up on ridges $c .30 \mu \mathrm{m}$ high and 15-20 $\mu \mathrm{m}$ wide; ridges often sinuous, becoming narrower and lower towards equator where they become wider and commonly somewhat higher again (Pl. 1, fig. 3). Curvaturae rarely seen as faint, raised ridges, c. 20-25 $\mu \mathrm{m}$ broad. Exine 10-15 $\mu \mathrm{m}$ thick, smooth, semi-lustrous, appearing light-medium orange-brown to dark brown.

Stratigraphic occurrence. Abundant in the 'Grey Beds' transition and lower Åre-1 Formation, where it is the index taxon for the Banksisporites pinguis Zone (Middle-Upper Rhaetian).

Remarks. Our material compares closely with specimens described from the Rhaetian of the Rødby-1 borehole, Denmark (Bertelsen \& Michelsen, 1970) and the Mechowo 1 Borehole, Poland (Marcinkiewicz, 1962).

Genus Verrutriletes van der Hammen, 1954 ex Potonié, 1956

Verrutriletes franconicus Jung, 1960

(P1. 2, figs 2, 3)

Material. Nineteen specimens from several Haltenbanken wells.

Description. A medium-sized trilete megaspore, subtriangular in equatorial outline, $380-500 \mu \mathrm{m}$ in equatorial diameter. Laesurae extend to 0.9 radius of spore on ridges $c .15 \mu \mathrm{m}$ high and $15 \mu \mathrm{m}$ broad. Curvaturae are narrow raised ridges, c. $15 \mu \mathrm{m}$ broad.
Exine $10-15 \mu \mathrm{m}$ thick, light orange-brown; proximal surface sculptured with fine to globular verrucae $10-20 \mu \mathrm{m}$ in diameter. Distal surface smooth and lustrous.

Stratigraphic occurrence. This is generally a rare species, ranging through the Åre 2.4-2.2 units, Kuqaia quadrata Zone, Subzone A.

Remarks. Our material is similar to that described by Jung (1960) and Bertelsen \& Michelson (1970), although the verrucae are more subtly developed: as a result it is difficult to identify this species, especially when preservation is poor.

Verrutriletes utilis (Marcinkiewicz, 1962) Marcinkiewicz, 1969 (P1. 2, figs 4, 5)

Material. Forty-six specimens from several Haltenbanken wells.

Description. A medium-sized trilete megaspore, circular in equatorial outline, $400-600 \mu \mathrm{m}$ in equatorial diameter. Laesurae straight, extend to $0.8-0.9$ radius of spore on prominent, raised ridges $c .20 \mu \mathrm{m}$ high and $15 \mu \mathrm{m}$ broad. Curvaturae distinct, forming narrow, raised ridges $c .20 \mu \mathrm{m}$ high and $15 \mu \mathrm{m}$ broad. Exine 10-15 $\mu \mathrm{m}$ thick, light orange-brown; contact area of proximal face nearly smooth or covered with small verrucae $<10 \mu \mathrm{m}$ in diameter (Pl. 2, fig.4); distal surface sculptured with fine to coarse, globular verrucae up to $20 \mu \mathrm{m}$ in diameter (Pl. 2, fig. 5).

Stratigraphic occurrence. Recorded commonly from the lower Åre-1 Formation where it is restricted to the Banksisporites pinguis Zone (Middle-Upper Rhaetian).

Remarks. Our material differs from that of Bertelsen \& Michelsen (1970) in having narrower triradiate ridges and curvaturae, and in lacking striations on the contact surface. A wide range of variation is seen in the size and density of verrucae, with many specimens appearing almost smooth: this may be partly attributable to preservational differences.

\section{Verrutriletes sp. 1 \\ (P1. 2, figs 6, 7)}

Material. Fifty-one specimens from wells 6508/5-1 and 6608/ $11-5$.

Description. A large, trilete megaspore, circular in equatorial outline, $700-800 \mu \mathrm{m}$ in equatorial diameter (mature specimens). Laesurae straight, extending to 0.9 radius of spore on prominent ridges c. $40 \mu \mathrm{m}$ high except near equator where they become lower. Curvaturae evident either as a faint line of discontinuity between coarse and fine verrucae or as a ridge some $20 \mu \mathrm{m}$ high. Exine $10-15 \mu \mathrm{m}$ thick, dark orange-brown, sculptured with coarse, rather irregularly shaped verrucae up to $40 \mu \mathrm{m}$ in diameter, sometimes coalescing to form wedge-shaped elements (P1. 2, fig. 7); size of verrucae on contact face generally somewhat reduced, being mainly $10-20 \mu \mathrm{m}$ in diameter.

Stratigraphic occurrence. Verrutriletes sp. 1 occurs commonly in the lower Åre-1 Formation in association with Banksisporites 

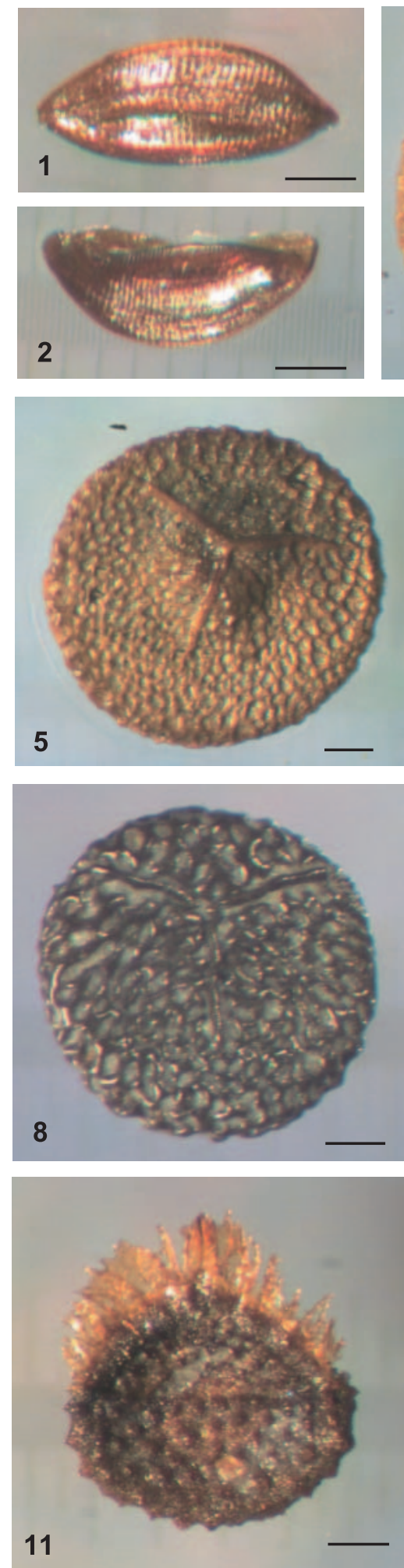
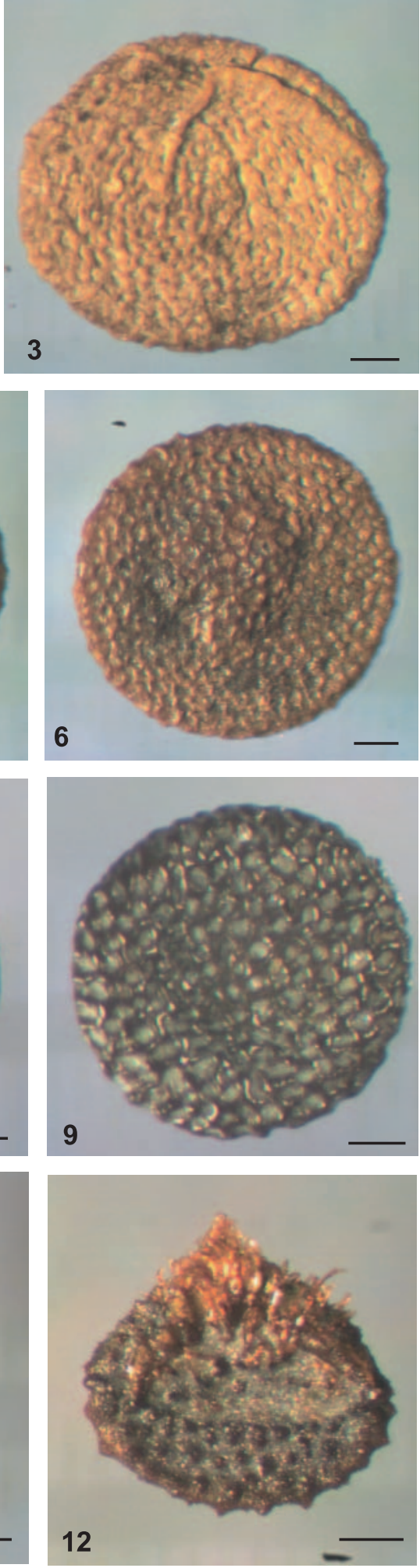

Explanation of Plate 3.

figs 1, 2. Kuqaia quadrata Li Wen-ben, 1993, 6608/10-7, $2030.70 \mathrm{~m}$; dorsal and lateral views, respectively; MPK13776, 13777. figs 3-6. Horstisporites areolatus (Harris, 1935), compressed specimens: 3, oblique proximal, 4, proximal and 5, 6 (same specimen) proximal and distal views from 6608/11-4, $1950 \mathrm{~m}, 6507 / 8-\mathrm{D}-3 \mathrm{AHT} 2,2902.50 \mathrm{~m}$ and 6608/11-4, $1962 \mathrm{~m}$, respectively; MPK13778-13780. figs 7-9. Horstisporites sp. cf. H. rexargenteus (Harris, 1935), 6608/11-5, 1593 m, partly compressed specimens: 7, oblique lateral and 8, 9 (same specimen) proximal and distal views; MPK13781, 13782. figs 10-13. Nathorstisporites hopliticus Jung, 1958, partly compressed specimens: 10, 11, 12, lateral and 13, proximal views (10, 13, 6608/11-4, $2046 \mathrm{~m} ; \mathbf{1 1}, \mathbf{1 2}, 6507 / 12-3,2589 \mathrm{~m})$; MPK13783-13786. Scale bars represent $100 \mu \mathrm{m}$.
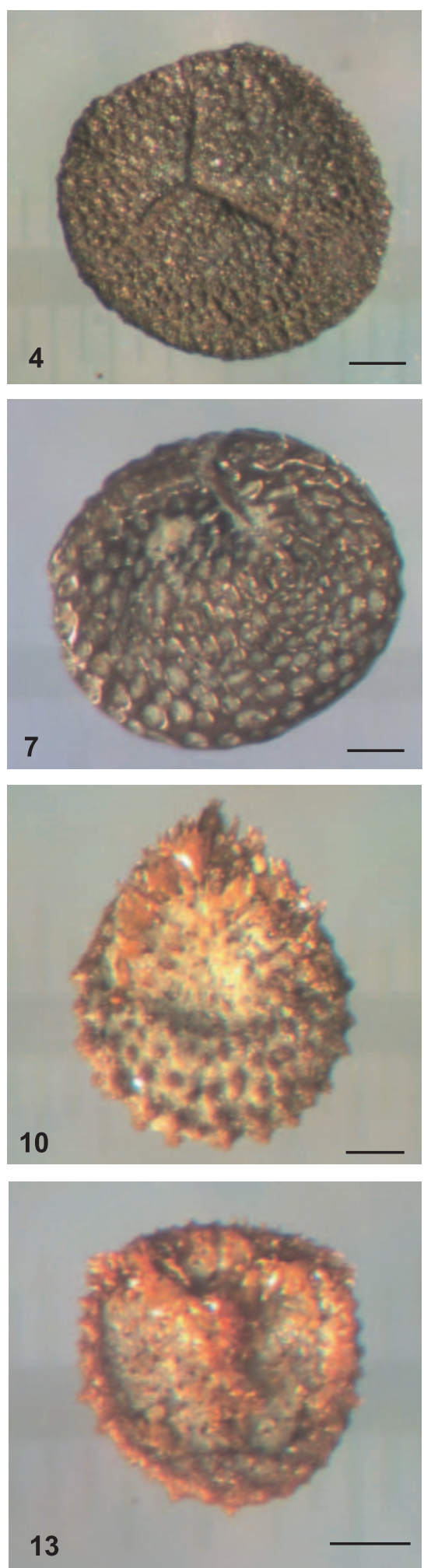

13 
pinguis, and appears to be restricted to the Banksisporites pinguis Zone, Subzone A (Middle-Upper Rhaetian).

Remarks. This species is similar to Verrutriletes utilis but differs in being both more robust and more coarsely sculptured.

Genus Bacutriletes van der Hammen, 1954 ex Potonié, 1956

Bacutriletes reticuliferus Bertelsen \& Michelsen, 1970

(P1. 2, figs 8-10)

Material. Ten specimens from 6608/11-4 and 6608/11-5.

Description. A small trilete megaspore, subtriangular-circular in equatorial outline, $150-180 \mu \mathrm{m}$ in equatorial diameter. Laesurae straight, extending to $0.6-0.8$ radius of spore on ridges that are commonly obscured by dense, small bacula $<5 \mu \mathrm{m}$ in diameter and $c .10 \mu \mathrm{m}$ high, which cover whole surface of spore. Contact area between triradiate ridges tends to be concave as a result of compaction, which produces a trigonal-shaped apex (Pl. 2, fig. 10). Exine thick (unable to determine precise thickness from any specimens), light-dark orange-brown.

Stratigraphic occurrence. Occurs rarely in the lower Åre-1 Formation, apparently restricted to the Banksisporites pinguis Zone, Subzone A (Middle-Upper Rhaetian).

Remarks. Our specimens differ from those of Bertelsen \& Michelsen (1970) in having a smaller average equatorial diameter. The presence of a fine, imperfect reticulate sculpture, described by Bertelsen \& Michelsen (1970), is not apparent under reflected light; examination under a scanning electron microscope is necessary to see it.

Bacutriletes tylotus (Harris, 1935) Potonié, 1956

(Pl. 2, figs 11-13)

Material. Two hundred and seventeen specimens from several Haltenbanken wells.

Description. A medium-sized trilete megaspore, circular in equatorial outline, $350-500 \mu \mathrm{m}$ in equatorial diameter. Laesurae straight, extending to $0.6-0.8$ radius of spore on ridges that are often obscured by sculpture of closely spaced bacula $5-15 \mu \mathrm{m}$ in diameter and height, which cover whole surface of spore, sometimes coalescing to form truncated cones with comparatively wide spaces $(20-30 \mu \mathrm{m})$ in between (Pl. 2, fig. 13). Curvaturae present as depressions or raised ridges $10-15 \mu \mathrm{m}$ broad, although in most specimens they are obscured by bacula. Exine $10-15 \mu \mathrm{m}$ thick, light-dark orange-brown.

Stratigraphic occurrence. Ranges from the lower Åre-1 Formation into the upper Åre-2 Formation, occurring most consistently in the Åre-1, Banksisporites pinguis Zone (Middle-Upper Rhaetian). Specimens from the Åre-1 Formation tend to be more heavily ornamented and robust than those from the younger Åre-2 Formation.
Remarks. Our material displays a wide range of variation in the size and density of the bacula, in accordance with the description of Bertelsen \& Michelsen (1970).

Genus Horstisporites Potonié, 1956

Horstisporites areolatus (Harris, 1935) Potonié, 1956

(P1. 3, figs 3-6)

Material. Over 300 specimens from several Haltenbanken wells.

Description. A comparatively large trilete megaspore, circular in equatorial outline, $700-850 \mu \mathrm{m}$ in equatorial diameter. Laesurae straight, extending to $0.7-0.8$ radius on low ridges c. $25 \mu \mathrm{m}$ broad that taper towards their extremities. Exine $15-20 \mu \mathrm{m}$ thick, light-dark orange brown, sculptured with a perfect reticulum of slightly rounded muri forming a polygonal meshwork; lumina $20-40 \mu \mathrm{m}$ in diameter and $<10-15 \mu \mathrm{m}$ deep, varying according to size and degree of compaction.

Stratigraphic occurrence. A common species, its range overlaps that of Nathorstisporites hopliticus in the Are-1 Formation, becoming dominant as the index taxon of the Horstisporites areolatus Zone, upper Åre-1 Formation (Upper Hettangian).

Remarks. Our material compares closely with published descriptions of this species. In gross morphology Horstisporites areolatus is similar to Horstisporites sp. cf. H. rexargenteus of the present study, the latter differing in having a thicker exine, narrower triradiate ridges and broader and, perhaps, generally slightly deeper, lumina.

\section{Horstisporites sp. cf. H. planatus (Marcinkiewicz, 1960) Marcinkiewicz, 1971 \\ (Pl. 2, fig. 1)}

Material. Six specimens from wells 6608/10-H-1H, 6608/11-6 and 6507/6-3.

Description. A medium-sized trilete megaspore with subtriangular equatorial outline, $370-500 \mu \mathrm{m}$ in equatorial diameter. Straight triradiate ridges $c .50 \mu \mathrm{m}$ high and $40 \mu \mathrm{m}$ broad extend to 0.9 radius of spore. Curvaturae consist of prominent ridges c. $40 \mu \mathrm{m}$ broad. Exine $15 \mu \mathrm{m}$ thick, light orange-brown, coarsely granular in distal and equatorial regions; proximal face covered with verrucae, which become larger $(10-15 \mu \mathrm{m}$ in diameter) towards apex.

Stratigraphic occurrence. This is a rare species which occurs sporadically through the Åre 2.2-2.5 units, Kuqaia quadrata Zone, subzones A-B.

Remarks. Our material is similar to Horstisporites planatus but appears to possess coarser verrucae on the proximal face.
Horstisporites sp. cf. H. rexargenteus (Harris, 1935) Potonié, 1956
(P1. 3, figs 7-9) 
Material. Fifty-three specimens from wells 6608/11-4, 6608/11-5 and 6508/11-1.

Description. A medium-sized trilete megaspore, circular in equatorial outline, $450-550 \mu \mathrm{m}$ in equatorial diameter. Laesurae straight, extending to $0.7-0.8$ radius on low, narrow ridges c. $10 \mu \mathrm{m}$ broad. Curvaturae faintly visible as a thin line of discontinuity in reticulate sculpture. Exine $20-25 \mu \mathrm{m}$ thick, medium-dark brownish black with coarsely reticulate surface; reticulum perfect, consisting of rounded muri $10-15 \mu \mathrm{m}$ wide encompassing broadly rounded lumina $35-45 \mu \mathrm{m}$ wide and generally $<15 \mu \mathrm{m}$ deep, although this varies with size and degree of compaction.

Stratigraphic occurrence. This species occurs commonly in the Banksisporites pinguis Zone, Subzone A, ranging to the upper Åre-1 Formation (Middle-Upper Rhaetian).

Remarks. Horstisporites sp. cf. H. rexargenteus is similar to Horstisporites areolatus, but differs as noted under 'Remarks' above.

Genus Nathorstisporites Jung, 1958

Nathorstisporites hopliticus Jung, 1958

(P1. 3, figs 10-13)

Material. Over 300 specimens from several Haltenbanken wells.

Description. A medium-sized trilete, zonate megaspore, circular to subtriangular in equatorial outline, $400-450 \mu \mathrm{m}$ in equatorial diameter. Laesurae straight, reaching equator, bordered by highly elevated membranous lips that are deeply incised and partly comprise bifurcating capilli that extend up to $170 \mu \mathrm{m}$ at proximal pole, decreasing in height towards equator (P1. 3, figs 10, 11). Contact face delimited by a low exinous elevation that is parallel to equator. Exine $15-20 \mu \mathrm{m}$ thick, light-medium orange-brown, covered with coni or spines $c$. 25-30 $\mu \mathrm{m}$ in diameter at base and $20-25 \mu \mathrm{m}$ in height; in many cases elements probably originally higher than this, extending into long capilli on proximal face in between triradiate flange but now largely missing as a result of exine degradation; bases of elements generally appearing somewhat broader and evenly distributed on distal surface, intervening spaces being c. 20-50 $\mu \mathrm{m}$ wide.

Stratigraphic occurrence. A common species in the Åre-1 Formation where its consistent occurrence defines the Nathorstisporites hopliticus Zone (Lower-Middle Hettangian).

Remarks. Our material compares closely with previously published descriptions and illustrations of specimens of this species, including those previously assigned to Lycostrobus scotti Nathorst (e.g. by Lundblad, 1956).

\section{Incertae sedis \\ Genus Kuqaia Li Wen-ben, 1993}

Kuqaia quadrata Li Wen-ben, 1993

(P1. 2, figs 14, 15; P1. 3, figs 1, 2)
Material. Over 600 specimens from several Haltenbanken wells.

Description. A small-medium-sized organic-walled body with a fusiform outline in inferred dorso-ventral view (Pl. 2, fig. 14; Pl. 3, fig. 1); length $350-400 \mu \mathrm{m}$, width $150-160 \mu \mathrm{m}$ in uncompressed examples. Compacted specimens, which are more common, appear roughly semi-circular (P1. 2, fig. 15) and may be split and opened out ventrally, commonly with a ragged or irregular edge when this has resulted from compaction (Pl. 2, fig. 15). Specimens ornamented with numerous intersecting concentric and radial ribs $<5 \mu \mathrm{m}$ broad that create a distinctive reticulate pattern (Pl. 2, fig. 15). Wall 3-5 $\mu \mathrm{m}$ thick, lustrous and translucent, medium-dark reddish brown.

Stratigraphic occurrence. A very common species, ranging from the uppermost Åre-1 Formation to the uppermost Åre-2 Formation where it characterizes the Kuqaia quadrata Zone (Sinemurian-Lower Pliensbachian).

Remarks. Li Wen-ben (1993) distinguished three species of Kuqaia from the non-marine Yangxia Formation (Lower Jurassic) in Xinjiang, China, based on the relative prominence of the concentric versus the radial ridges that comprise the ornament. In a later paper, a further two species were erected and one new combination of a species previously assigned to the megaspore genus Aneuletes was established by Cui et al. (2004) based on other Early Jurassic material from Xinjiang.

No attempt has been made to distinguish different species in our study because the relative robustness of the concentric and radial ridges was found to vary with the degree and angle of compaction, and state of preservation. The morphology of uncompacted, well-preserved specimens is closely comparable to that of Kuqaia quadrata, as described by Li (1993); hence, this species name is applied here in a broad sense to all of the specimens recovered.

\section{MEGASPORE/MESOFOSSIL BIOSTRATIGRAPHY, HALTENBANKEN REGION}

\section{'Grey Beds'-Åre-1 Formation}

The distribution of megaspores through the 'Grey Beds'-Åre Formation in wells 6608/11-4 and 6608/11-5 highlights a distinct megaspore succession, which followed deposition of the 'Red Beds' (Figs 3, 4). The upper 'Red Beds' yield rich ostracod assemblages, dominated by Rhombocythere spp., including the zonal species Rhombocythere penarthensis, and are widely correlatable within the Upper Norian-Lower Rhaetian (Christensen, 1962; Simon \& Bartenstein, 1962; Bate \& Robinson, 1978). Description of the microfauna is, however, beyond the scope of this paper.

The interval immediately above the 'Red Beds' in both wells has not yielded any significant in situ microfauna or palynoflora: consequently, it is unzoned (Figs 3, 4). In 6608/11-4, megaspores first appear within the 'Grey Beds' with the identification of Banksisporites pinguis at $2178 \mathrm{~m}$, although, in 6608/11-5, the first definite record of this species is higher, coinciding with the base of the Åre-1 Formation (Fig. 4). This 'event', which can be widely correlated (see below), defines the base of the Banksisporites pinguis Zone. 
In 6608/11-4, a modest increase in megaspore abundance and diversity is evident through beds of the lower Åre-1 Formation compared with 6608/11-5 (Fig. 4); however, in the former well, the samples were more widely spaced $(12 \mathrm{~m})$ and processed for megaspores at an early stage in the investigation when laboratory procedures were less refined: consequently, the megaspore biostratigraphy of $6608 / 11-5$ is considered to be more representative of this part of the formation. Relatively diverse megaspore floras are established within the lower part of the lower Åre-1 Formation, represented by Banksisporites pinguis, Bacutriletes tylotus, B. reticuliferus, Verrutriletes utilis, Verrutriletes sp. 1 and Horstisporites sp. cf. $H$. rexargenteus. Towards the top of the unit, a changeover in this flora is evident, with extinctions of a number of taxa at or near $1568.50 \mathrm{~m}$, within a thick carbonaceous claystone sequence (Fig. 4). Last occurrences of Verrutriletes sp. 1, Horstisporites sp. cf. H. rexargenteus and Bacutriletes reticuliferus at this level mark the top of Subzone A within the Banksisporites pinguis Zone. Above this level, which is cored in $6608 / 11-5$, increased species dominance of $B$. pinguis is evident, with the appearance of Tasmanitriletes sp. cf. $T$. pedinacron, this marking Subzone B of the B. pinguis Zone (Fig. 4). For the reasons already stated and the lack of core, this subzone is not recognized in 6608/11-4; however, the B. pinguis Zone can be widely correlated and, on regional evidence, extends beyond the Haltenbanken area with the last occurrence of B. pinguis marking top Rhaetian (see below).

In well 6608/11-5, megaspores above the B. pinguis Zone are missing owing to erosion beneath the base Cretaceous Unconformity. In 6608/11-4, however, which is downflank of the Rødøy High (Fig. 1b), a more complete Åre Formation succession is present and, in this, the highest occurrence of B. pinguis occurs in carbonaceous claystones some $60 \mathrm{~m}$ below 'Coal A' (Fig. 3). This species is succeeded by Nathorstisporites hopliticus, which ranges up to the middle part of 'Coal B', defining the $N$. hopliticus Zone. Based on the 6608/11-4 well data, N. hopliticus reaches its acme within 'Coal A', above which Horstisporites areolatus becomes dominant. These changes provide a provisional basis for placing the boundary between Subzone A and Subzone B of the $N$. hopliticus Zone within 'Coal A' (Fig. 3).

In 6608/11-4, megaspore assemblages dominated by Horstisporites areolatus extend from the middle part of 'Coal B' up into the overlying claystones of the upper Åre-1 Formation, defining the Horstisporites areolatus Zone (Fig. 3). Towards the top of this zone there is overlap between $H$. areolatus and the succeeding assemblage, with the first common occurrence of Kuqaia quadrata, a microfossil of hitherto undetermined affinity, as noted above, coinciding with the last occurrence of $H$. areolatus at $1878 \mathrm{~m}$, near the top of the Åre-1 Formation. This overlap provides a basis for defining an upper Subzone B within the $H$. areolatus Zone (Fig. 3). Above this, at $1854 \mathrm{~m}$, a rare occurrence of Trileites candoris was recorded near the base of the Kuqaia quadrata Zone, and this can be correlated with other wells (e.g. 6608/10-6). Low diversity megaspore assemblages dominated by Kuqaia quadrata extend across the Åre-1/Åre-2 boundary.

\section{Åre-2 Formation}

Megaspore/mesofossil distribution through the Åre-2 Formation in 6608/11-4 highlights the predominance of Kuqaia quad- rata, with few associated megaspore species present to indicate floral changes within this unit (Fig. 3). This is attributed to the quality of cuttings analysed and the processing technique used in the initial phase of our study. Infill core analysis of upper subunits, however, revealed the presence of the large, but comparatively fragile megaspore Trileites sp. 3 .

More detailed megaspore analysis of the Åre-2 Formation was undertaken in the Urd Field area, which is sited some $17 \mathrm{~km}$ south of 6608/11-4 (Block 6608/10; Fig. 1b, c). Evaluation of the megaspore/mesofossil biostratigraphy in this area was based on the analysis of eight exploration and production wells, representing the stratigraphy in all field sectors. Data from well $6608 / 10-\mathrm{J}-1 \mathrm{H}$ is presented here to illustrate the biostratigraphy of, and key 'bioevents' in, the Åre-2 Formation (Fig. 5).

The appearance of Trileites spp. in the lowermost part of Åre-2 (units 2.1-2.3) is characteristic, with Trileites sp. 3 being most notable. In other wells (not illustrated) the reappearance of Bacutriletes tylotus is also seen within claystones of these subunits.

Further floral changes are associated with claystones of the Åre 2.4-2.5 units, namely the inception of Trileites sp. 1, which, despite the difficulties caused by caving, can be correlated in most Urd Field wells, the 'event' defining the base of Subzone B of the Kuqaia quadrata Zone (Fig. 5). Associated with this appearance is an increase in numbers of Trileites sp. 3, this species tending to be consistently common-abundant through Subzone B. In other field wells Bacutriletes tylotus occurs sporadically within the upper part of this subzone, eventually petering out within Åre unit 2.7.

Moderately diverse megaspore assemblages characterized by Trileites sp. 1, common-abundant Trileites sp. 3, sporadic Bacutriletes tylotus, along with common-abundant Kuqaia quadrata, continue to the top of Åre 2.7, this marking the limit of Subzone B. Above this level (lower Åre 2.8), there is a reduction in megaspore/mesofossil abundance and diversity, with Kuqaia quadrata and Trileites sp. 3 only occurring in the uppermost unit where this is present (e.g. in 6608/10-J-1H; Fig. 5) and not eroded away.

The termination of megaspore floras at the base of the Tilje Formation is abrupt, reflecting a shift towards coastal plain deposition in the Upper Pliensbachian (Pedersen et al., 1989).

\section{MEGASPORE BIOZONATION AND RELATIONSHIP TO MIOSPORE/MICROPLANKTON BIOEVENTS}

Composite ranges for megaspore species and Kuqaia quadrata in the Åre-1 and Åre-2 formations based on our well studies are shown in Figure 6. It is notable that whilst the number of megaspore species present at any one stratigraphical level is low, with a total of 17 species recorded from the Åre Formation, many individual ranges appear to be stratigraphically restricted, as do certain acme 'events' (e.g. Bankisporites pinguis, Nathorstisporites hopliticus, Horstisporites areolatus). This provides the basis for a high resolution zonation of the Åre Formation, which is relatively easy to apply, given the processing and logging techniques described.

As previously stated, palynological assemblages in the Åre Formation are dominated by morphologically diverse, longranging miospores, which have proved biostratigraphically unreliable in the northern Haltenbanken region. Nevertheless, a 


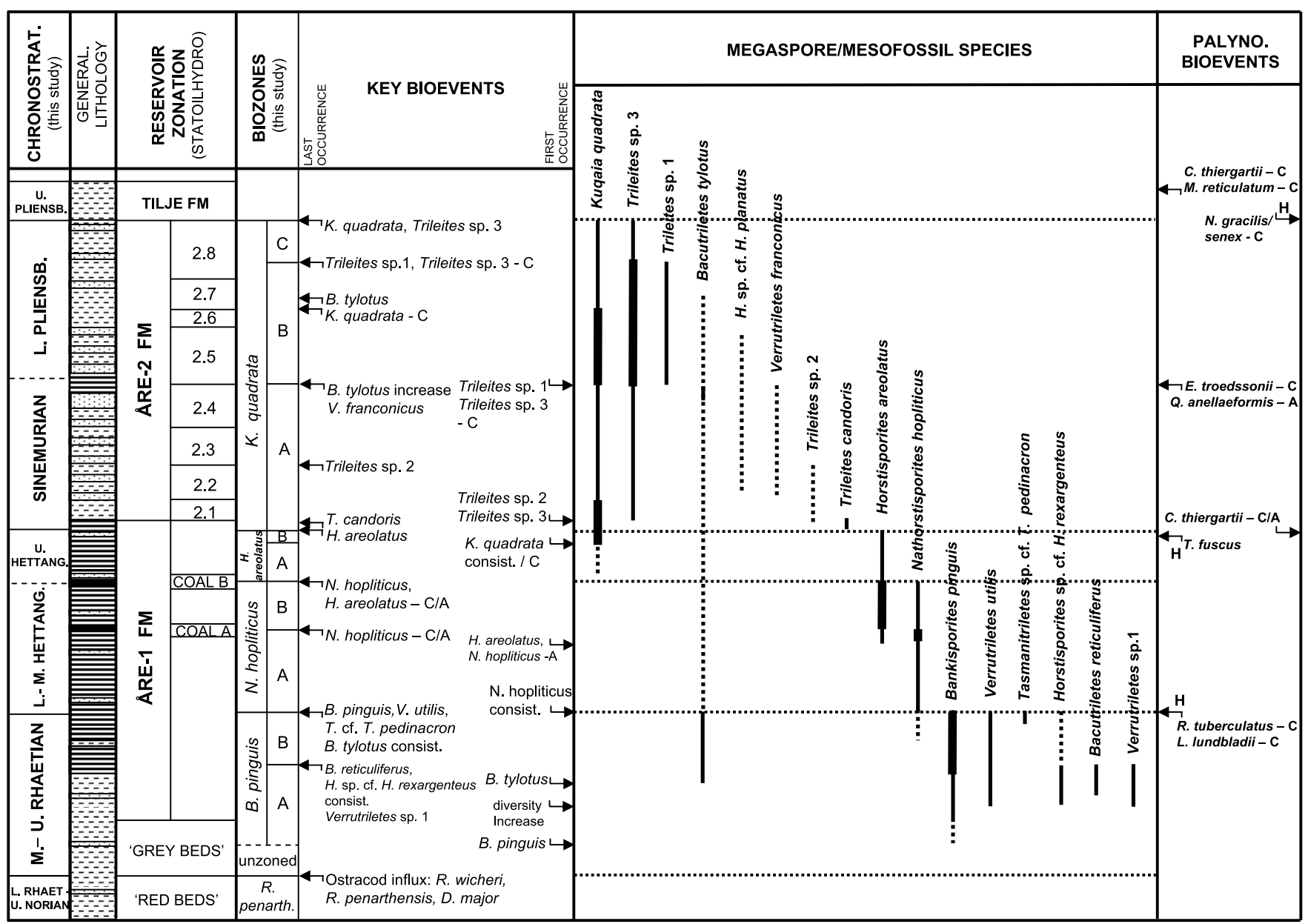

Fig. 6. Megaspore/mesofossil biozonation scheme for the Åre Formation, Haltenbanken region, showing composite ranges of key taxa plotted against palynology and interpreted chronostratigraphy (this study). Palynological events, mainly miospores, are based on occurrences in wells 6608/11-5, 6608/10-7 and 6507/6-3. H indicates palynogical event identified in the Heidrun Field (Pedersen et al., 1989).

number of miospore bioevents were used for correlation within the Åre Formation at field level further south (Heidrun: Pedersen et al., 1989), and some of these also have regional chronostratigraphical value (Lund, 1977; Batten \& Koppelhus, 1996). An attempt was also made to calibrate the occurrences of Nathorstisporites hopliticus and Banksisporites pinguis with miospore events in the Statfjord Formation, North Viking Graben (Charnock et al., 2001; see below).

At the time of writing only a limited number of Haltenbanken exploration wells have been analysed for both megaspores and miospores, including 6608/11-5, 6608/10-7 and recently completed 6507/6-3. A summary of miospore/microplankton events based on data from these wells is shown against the megaspore biozonation in Figure 6. The miospore bioevents indicated $(\mathrm{H})$ are also defined in the Heidrun Field (Pedersen et al., 1989) and overall these can be used to provide additional chronostratigraphical calibration of megaspore bioevents beyond the known occurrence of megaspore species (see below). On this basis the Banksisporites pinguis Zone can be confidently placed in the Middle-Upper Rhaetian, with its top corresponding to that of the uppermost Triassic, Ricciisporites tuberculatus/Limbosporites lundbladii event, which is also recognized in the North Viking Graben (Charnock et al., 2001).
The succeeding Nathorstisporites hopliticus Zone and Horstisporites areolatus Subzone A coincide with the last occurrences of common Ricciisporites tuberculatus and Limbosporites lundbladii at its base and the first occurrence of Trachysporites fuscus at its top, giving a Hettangian assignment, with the top of this stage occurring close to the upper Horstisporites areolatus Zone boundary (Fig. 6). In the North Viking Graben the extinction of Nathorstisporites hopliticus coincides with the appearances of Cerebropollenites mesozoicus and C. macroverrucosus at the base of the Upper Hettangian (Charnock et al., 2001) in support of this assignment, and tentatively indicates a Middle Hettangian age for the top of the Nathorstisporites hopliticus Zone (Fig. 6). The base of the Kuqaia quadrata Zone, which occurs near the top of the Åre-1 Formation, coincides with the first occurrence of common/abundant Cerebropollenites thiergartii at the base of the Sinemurian.

Bioevents within the Kuqaia quadrata Zone of the Åre-2 Formation are poorly constrained by miospores; however, the top of Subzone A, which is marked by a number of megaspore inception and extinction events within the 2.4/2.5 mudstone subunit (Fig. 6), coincides with the last occurrences of common Eucommiidites troedssonii and abundant Quadraeculina 
P. H. Morris et al.

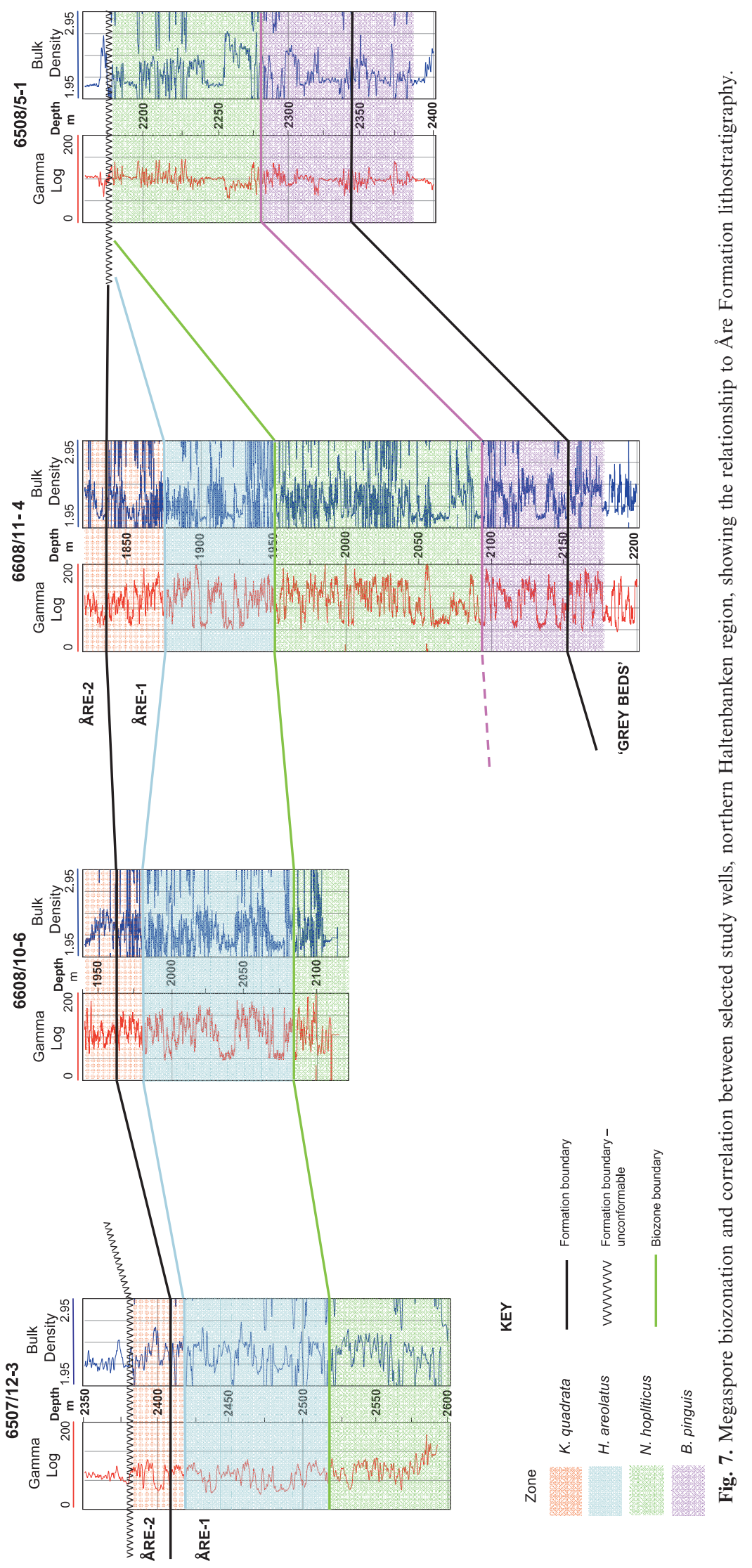


Megaspore assemblages from the Åre Formation, Norway
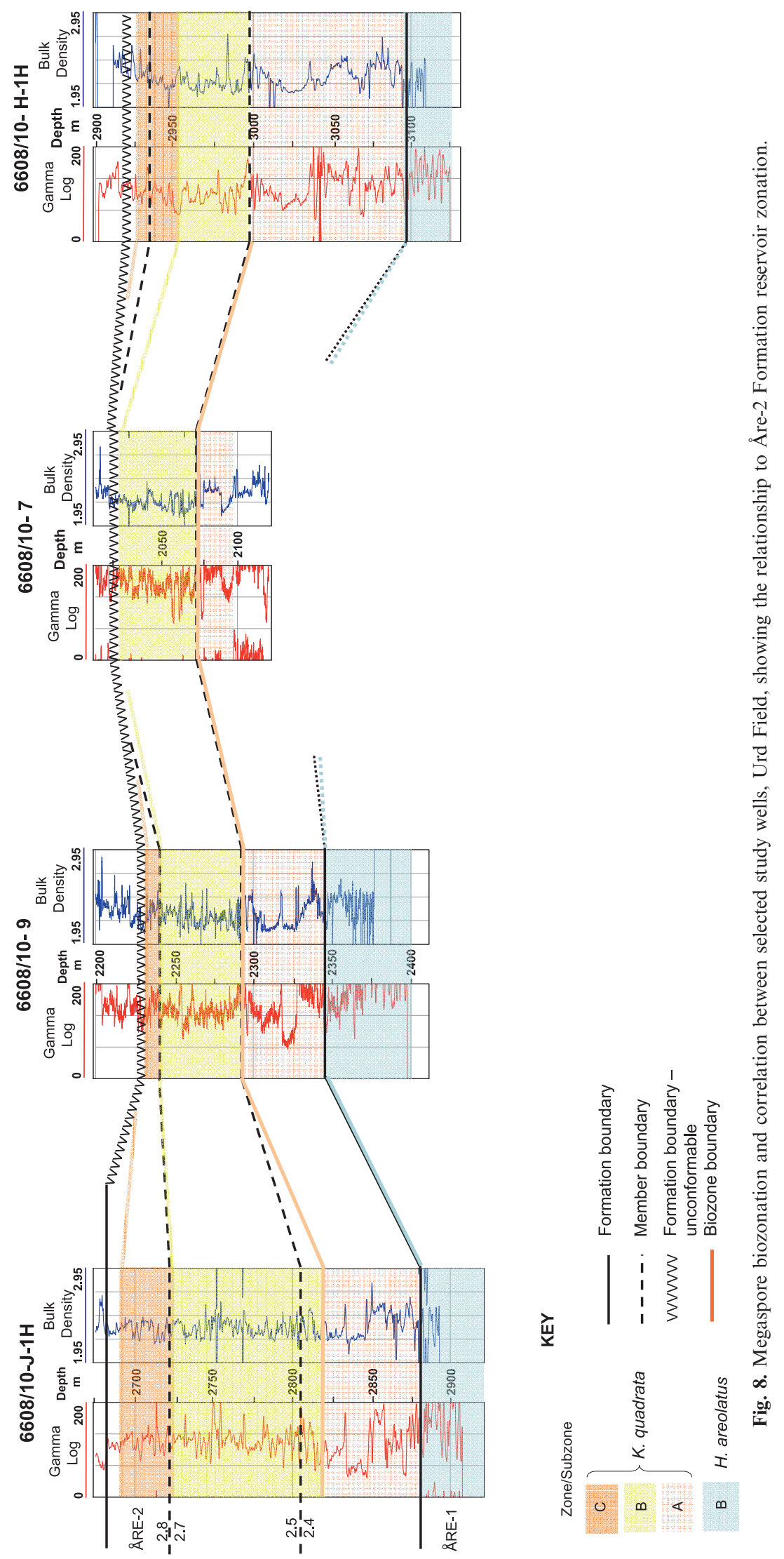
anellaeformis. This event marks top Sinemurian (StatoilHydro unpublished scheme) and is used here tentatively to date the Kuqaia quadrata Subzone A/B boundary (Fig. 6). The first occurrence of marine microplankton, represented by Nannoceratopsis gracilis and $N$. senex, is defined at the base of the Tilje Formation and is used regionally to indicate basal Upper Pliensbachian (see Pedersen et al., 1989). This provides an upper age constraint on the Kuqaia quadrata Subzones B-C, which can be placed within the Lower Pliensbachian (Fig. 6).

The chronostratigraphical calibration of megaspore biozones proposed here is compared with the published occurrences of megaspore species in the regional biostratigraphy section below.

\section{CORRELATION OF BIOZONES, HALTENBANKEN AREA}

The initial phase of our research involved wells from Blocks $6608 / 11$ and 6608/10, the results of which are presented above. Subsequently, megaspores and other mesofossils from the Åre Formation were evaluated in several exploration wells including 6508/5-1 (Trondelag Platform) and 6507/12-3 (Halten Terrace; see Fig. 1b). In these and other study, wells the same succession was identified, enabling correlation of the biozones recognized with stratigraphical sections within these areas, as shown in Figure 7. This correlation encompasses sequences extending over a distance of $120 \mathrm{~km}$ and three structural units, providing insight into (a) the age and stratigraphical relationship of the transition between the 'Grey Beds' and the Åre Formation; (b) the age and lateral extent of coals and carbonaceous-rich deposits, and reservoir horizons within the Åre Formation; and (c) the degree of erosion of units of this formation. Hence, the potential exists to evaluate the stratigraphy of the Are Formation across large areas of the Haltenbanken region using megaspores, and to extend the biozonal scheme into other basins where extensive Lower Jurassic, non-marine deposition has occurred (see below).

In addition, Figure 7 highlights the areal extent of the Kuqaia quadrata Zone, which is also identified in 6507/12-3. Correlation of subzones within the $K$. quadrata Zone across the Haltenbanken area has not been possible using the current database. However, our detailed analysis of the Åre-2 Formation in the Urd Field demonstrates that the changes in megaspore composition described above may be correlated across the field. Correlation of these subzones is shown in Figure 8 using selected study wells (see Fig. 1c for well locations). Key 'marker' shales within the reservoir interval are indicated, and changes in the megaspore assemblages broadly correspond to these shale breaks (e.g. the transition from Subzone A to Subzone B coincides with the Åre 2.4/2.5 boundary). Although the Åre-2 reservoir sequence can only be subdivided into three subzones, these can be used to reduce uncertainties in log-based correlation, especially where there is faulting-out or erosion of reservoir units.

\section{REGIONAL UPPER TRIASSIC JURASSIC MEGASPORE BIOSTRATIGRAPHY}

In reviewing the stratigraphical occurrences of megaspore species world-wide, Kovach \& Batten (1989) highlighted the inherent difficulties in accepting authors' identifications at face value. Consequently, they indicated that the total ranges given for some species are over-extended, with Banksisporites pinguis cited as a case in point. This species, which is an index taxon in the current study, is shown to range from Griesbachian (Lower Triassic) to Aptian/?Santonian, with a large gap through the Sinemurian-Berriasian. This suggests that different taxa are included or that morphologically similar forms evolved independently through the Mesozoic.

Other zonal taxa, including Nathorstisporites hopliticus and Horstisporites areolatus, are also shown to have broad stratigraphical ranges (Carnian-Toarcian and Carnian-Bathonian, respectively), which would appear to downgrade their regional biostratigraphical value. Indeed, the restricted stratigraphical ranges of key taxa evident in the Haltenbanken study wells are difficult to reconcile with their distribution based on the compilation of world-wide occurrences (Kovach \& Batten, 1989). On this basis, therefore, the ranges of key megaspore species in the Haltenbanken area (Fig. 6) appear to have been influenced by relatively local palaeoenvironmental controls, albeit over a wide offshore area. In considering the succession of Boreal megaspore floras in general, however, assemblage zonation rather than total range zonation provides greater resolution regionally.

During early palaeobotanical studies on outcrops, megaspore occurrences were tied to the established plant biozonation for the Rhaeto-Liassic section of East Greenland (Harris, 1935). In this and subsequent work (e.g. by Jung, 1960), distinct megaspore/plant associations were identified within the Rhaetian Lepidopteris ottonis and the Hettangian Thaumatopteris schenki zones. The stratigraphic ranges of megaspore species common to our study and previously published European investigations are given in Table 1.

It can be seen from this table that a distinct succession of megaspore floras is evident through the Rhaeto-Liassic interval. Initially Banksisporites pinguis assemblages become established within the Rhaetian and are replaced by Nathorstisporites hopliticus in the Hettangian. This flora is in turn succeeded by Horstisporites areolatus, which ranges with other species (e.g. Trileites candoris) into the Sinemurian. The similarity with the distribution of megaspores in the Are-1 Formation is striking, indicating that this was controlled by regional factors rather than by more localized palaeoenvironmental changes.

Where more continuous stratigraphical sections have been analysed in borehole studies (e.g. Marcinkiewicz, 1962; Bertelsen $\&$ Michelsen, 1970) further similarities are evident between the 'Red Beds'-Åre-1 Formation and the Upper Triassic-Lower Jurassic (Keuper-Lias) megaspore successions. In the Rødby-1 Borehole, offshore Denmark (Bertelsen \& Michelsen, 1970), unspeciated ostracod microfaunas are succeeded by Banksisporites pinguis megaspore assemblages in the Rhaetian, as in the 'Red Beds'-Åre Formation sections of 6608/11-4/5. It is noteworthy that the ostracod faunas, which have also been reported from North German Upper Triassic sections, consist of the same species of Rhombocythere (see Simon \& Bartenstein, 1962; Christensen, 1962). Following the initial appearance of Banksisporites pinguis in this well, the inceptions of Bacutriletes reticuliferus, Verrutriletes utilis and Tasmanitriletes pedinacron compare sequentially with those of the Åre-1 Formation; similarly the extinction of these species along with Banksisporites pinguis occurs at the same level (top Rhaetian).

The lowermost megaspore assemblages (Assemblage I) in the Mechowie-1 Borehole, northern Poland, described by 


\begin{tabular}{|c|c|c|c|}
\hline Megaspore species & $\begin{array}{c}\text { Rhaetian: L. ottonis Zone } \\
\text { (Keuper) }\end{array}$ & Transition & $\begin{array}{l}\text { Sinemurian or younger } \\
\qquad(\text { Lias } \alpha-\beta)\end{array}$ \\
\hline
\end{tabular}

\begin{tabular}{lc}
\hline Banksisporites pinguis & GDFPR \\
Bacutriletes tylotus & GDPR \\
Bacutriletes reticuliferus & R \\
Verrutriletes utilis & DP \\
Horstisporites rexargenteus & GR \\
Tasmanitriletes pedinacron & GDR \\
Nathorstisporites hopliticus & \\
Horstisporites areolatus & \\
Trileites candoris/regalis & \\
Verrutriletes franconicus & \\
Horstisporites planatus & \\
\hline
\end{tabular}

$\begin{array}{ccc}\text { D } & & \\ \text { D } & \text { F } & \\ & & \\ \text { D } & & \\ \text { G } & \text { GDSFPR } & \text { R } \\ & \text { SPR } & \text { SPR } \\ & \text { S } & \text { SP } \\ & \text { F } & \text { R } \\ & & \text { P }\end{array}$

G, Greenland: Harris (1935); D, North Germany: Simon \& Bartenstein (1962), Reinhardt (1963), Will (1969); F, South Germany: Jung (1960); P, Poland: Marcinkiewicz (1960, 1962); S, Scandinavia: Lundblad (1956), Gry (1969); R, Rødby-1, Denmark: Bertelsen \& Michelsen (1970).

Table 1. Previously published stratigraphical ranges of megaspore species occurring in the Åre Formation.

Marcinkiewicz (1962), are also characterized by Banksisporites pinguis, with Verrutriletes utilis, Bacutriletes tylotus and ?Horstisporites rexargenteus (?synonomous with $H$. cavernatus). A significant difference in these central European floras is, however, the presence of Minerisporites ales, which seems to be virtually absent from the 'Grey Beds'-Åre-1 Formation (one specimen only found recently in 6508/5-1).

The overlying Lias $\alpha$ equivalent in the Rødby-1 and Mechowie-1 boreholes yielded the same megaspore succession as the Åre-1 Formation, with low diversity floras dominated by Nathorstisporites hopliticus succeeding Banksisporites pinguis assemblages in the basal Hettangian (probable pre-planorbis beds; see Bertelsen \& Michelsen, 1970). The overlap in stratigraphical range between Nathorstisporites hopliticus and Horstisporites areolatus, evident in the Åre-1 Formation (Fig. 6), is also apparent in both Rødby-1 and Mechowie-1 boreholes, despite increasing marine influence evident in the former from the association of the index ostracod Ogmoconchella aspinata through the $N$. hopliticus $-H$. areolatus zones. In both boreholes the upper Lias $\alpha$ sequence is either absent or unsampled, so further comparisons are not possible.

The above similarities in the megaspore succession strongly suggest that the megaspore biostratigraphy of the Åre-1 Formation was influenced by regional factors that affected a large geographical area, encompassing a significant part of the Central European Basin. One possibility is that the evolution and distribution of the plants involved were responding to widespread climatic change. A progressive increase in seasonal humidity through the Rhaetian (e.g. Ahlberg et al., 2002) would have favoured heterosporous lycopsids, aiding their rapid colonization of wet, poorly drained lowland tracts, conditions conducive to megaspore dispersal and germination.

Owing to the widespread development of deepening marine facies through the Sinemurian-Pliensbachian of the Central European Basin (Ziegler, 1990), regional comparison of megaspore assemblages from the Åre-2 Formation is more difficult, with the most characteristic species, the non-megaspore Kuqaia quadrata, not reported in previous European studies. The original recovery of this species from the Lower Jurassic in Xinjiang, China (Li, 1993) suggests, however, that it is widely distributed. This is further supported by its occurrence in the Rønne Formation of Bornholm (Batten, pers. obs.) and the Statfjord-lower Amundsen formations of the North Viking Graben (see below).

Most of the megaspores recorded from the Åre-2 Formation are species of Trileites identified in open nomenclature, so it is not possible at present to evaluate their regional distribution on the basis of comparisons with the published literature. However, Bacutriletes tylotus becomes extinct and Verrutriletes franconicus and Horstisporites sp. cf. H. planatus have their inceptions and extinctions within this unit (Fig. 6). From Table 1 it can be seen that the stratigraphic occurrence of these species is broadly consistent, although Bacutriletes tylotus ranges above the Hettangian in the Haltenbanken area. These limited comparative data suggest that the Åre- 2 Formation is partly equivalent to Lias $\beta$ (Sinemurian): it also indicates that regional lycopsid evolution was maintained, although at this time it may have become more restricted geographically to the northern Boreal realm.

\section{FUTURE POTENTIAL OF UPPER TRIASSIC-JURASSIC MEGASPORE BIOSTRATIGRAPHY}

The regional value of megaspore biostratigraphy, which was clearly evident from the earlier studies on northern Haltenbanken wells, is currently being rigorously tested in several field areas by StatoilHydro. The possibility that non-marine facies of the Statfjord Formation, further south in the Viking Graben, could be zoned using megaspores, was evaluated in the Gullfaks Field area (Block 34/10) in 2007. The initial pilot study, involving six well sections, confirmed the presence of the Banksisporites pinguis, Nathorstisporites hopliticus, Horstisporites areolatus and Kuqaia quadrata zones, and their subzones. Remarkably, the megaspore biozonation proposed could be applied directly to the Statfjord reservoir succession with little modification, providing additional evidence for regional (palaeoclimatic?) controls on the distribution of heterosporous plants and, hence, on the dispersal of their spores. Since this pilot study, a field-wide evaluation has been established to provide a comprehensive biozonation of the Statfjord Formation reservoir, and is currently in progress. Presentation of these oil-field data is beyond the scope of the present paper; it is mentioned simply to reinforce our argument that the potential 
biostratigraphical value of megaspores at both field and regional levels should not be overlooked.

In addition to the application of megaspore biostratigraphy to Lower Jurassic successions, there is growing evidence in the Haltenbanken area that megaspore assemblages also occur commonly in the Middle Jurassic Not and Melke formations, and can be correlated over a wide area (Morris, pers. obs.). The species encountered (e.g. Paxillitriletes phyllicus, Hughesisporites galericulatus) display a wide regional distribution, as for the Lower Jurassic. This indicates the possibility of extending the regional and field application of megaspores into younger Jurassic sections, especially where there is high reservoir potential (e.g. Brent Group, North Viking Graben).

\section{CONCLUSIONS}

The present study demonstrates that by using standard micropalaeontological techniques, megaspore assemblages can be effectively extracted from non-marine sediments of the Åre Formation. The results obtained show that a distinct megaspore succession is present within the unit, which can be divided into several assemblage zones. Associated miospore events and the known stratigraphic occurrence of megaspore taxa are integrated to provide a chronostratigraphical framework to constrain biozonal boundaries. A number of biozonation and age assignments are proposed.

1. Banksisporites pinguis Zone (Middle-Upper Rhaetian): defined on the presence of Banksisporites pinguis. Extinctions of Verrutriletes sp. 1, Horstisporites sp. cf. H. rexargenteus and Bacutriletes reticuliferus occur within the zone, indicating the top of Subzone A. The highest occurrences of Banksisporites pinguis, Tasmanitriletes sp. cf. T. pedinacron and Verrutriletes utilis mark the upper zonal boundary, which also coincides with a change in miospore assemblages, with the top occurrence of common Ricciisporites tuberculatus and Limbosporites lundbladii recorded at this level.

2. Nathorstisporites hopliticus Zone (Lower-Middle Hettangian): defined on the presence of Nathorstisporites hopliticus. Within this zone, the inception of Horstisporites areolatus is coincident with the acme of $N$. hopliticus defining the top of Subzone A/B boundary. Above this level, H. areolatus is predominant.

3. Horstisporites areolatus Zone (Upper Hettangian): defined on the presence of Horstisporites areolatus without Nathorstisporites hopliticus. The first consistent occurrence of Kuqaia quadrata defines the boundary between Subzones A and B.

4. Kuqaia quadrata Zone (Sinemurian-Lower Pliensbachian): defined on the presence of the mesofossil Kuqaia quadrata without Horstisporites areolatus. The lower zonal boundary coincides with the first common/abundant occurrence of the miospore Cerebropollenites thiergartii and the upper with the first common occurrence of the dinoflagellate cyst Nannoceratopsis gracilis/senex. The zone can be divided into three subzones in the Urd Field using the ranges of several informal species of Trileites, Verrutriletes franconicus and Bacutriletes tylotus.

Using selected wells the megaspore biozones are shown to correlate across the northern Haltenbanken region, providing a robust bio-chronostratigraphical framework with which to evaluate the stratigraphy of the Åre Formation, which has previously relied heavily on log-based correlation.

Evaluation of published megaspore occurrences through European Rhaeto-Liassic sections, together with continuing research in the Viking Graben, strongly suggest that the Haltenbanken megaspore biozones extend across the Central European Basin, reflecting regional, palaeoclimatic controls on the distribution of the megaspore-producing plants.

Finally, our research shows that megaspores are a stratigraphically important microfossil group, which deserves to be used more widely in Triassic-Jurassic oil field and regional biostratigraphical studies.

\section{ACKNOWLEGEMENTS}

The authors thank the management of StatoilHydro ASA and the PL128 licence partners ENI Norge and Petoro for permission to publish well data. They are indebted to geologists Anna Fawke, Lisa Michelson, Scott Alan Bullimore, Atle Jørgen Sande, Jostein Myking Kjærefjord and biostratigraphers Dave Hulks, Linn Johansen and Sissel Kvernes, all of StatoilHydro ASA, for supporting their megaspore research through field and regional well studies. Thanks are also due to David Bailey and Gwydion Williams for generating the palynological data cited, and John Athersuch for assistance with the ostracod taxonomy and literature. Finally, thanks are due to Nick Butler and an anonymous reviewer for constructive criticism of the manuscript, and to John Gregory for editorial assistance.

\section{Manuscript received 12 December 2008 Manuscript accepted 30 June 2009}

\section{REFERENCES}

Ahlberg, A, Arndorff, L. \& Guy-Ohlson, D. 2002. Onshore climate change during the Late Triassic marine inundation of the Central European Basin. Terra Nova, 14: 241-248.

Banerji, J., Kumaran, K.P.N. \& Maheshwari, H.K. 1978. Upper Triassic sporae dispersae from the Tiki Formation: megaspores from the Janar Nala section, South Rewa Gondwana Basin. The Palaeobotanist, 25: $1-26$.

Bate, R.H. \& Robinson, E. 1978. A stratigraphical index of British Ostracoda. Seel House Press, Liverpool, 538 pp.

Batten, D.J. \& Koppelhus, E.B. 1993. Morphological reassessment of some zonate and coronate megaspore genera of mainly postPalaeozoic age. Review of Palaeobotany and Palynology, 78: 19-40.

Batten, D.J. \& Koppelhus, E.B. 1996. Biostratigraphic significance of uppermost Triassic and Jurassic miospores in Northwest Europe. In: Jansonius, J. \& McGregor, D.C. (Eds), Palynology; Principles and Applications, 795-806. American Association of Stratigraphic Palynologists' Foundation, Dallas.

Batten, D.J. \& Kovach, W.L. 1990. Catalog of Mesozoic and Tertiary megaspores. American Association of Stratigraphic Palynologists, Contributions Series, 24: ii+227 pp.

Bertelsen, F. \& Michelsen, O. 1970. Megaspores and ostracods from the Rhaeto-Liassic section in the boring Rødby No. 1, southern Denmark. Danmarks Geologiske Undersogelse, Serie 2, 94: 60 pp., 17 pls. Blystad, P., Brekke, H., Faerseth, R.B., Larsen, B.T., Skogseid, J. \& Torudbakken, B. 1995. Structural elements of the Norwegian continental shelf. Part II: The Norwegian Sea region. Norwegian Petroleum Directorate, Bulletin, 8: 45 pp.

Charnock, M.A., Kristiansen, I.L., Ryseth, A. \& Fenton, J.P.G. 2001. Sequence stratigraphy of the Lower Jurassic Dunlin Group, northern North Sea. In: Martinsen, O.J. \& Dreyer, T. (Eds), Sedimentary Environments Offshore Norway - Palaeozoic to Recent. Norwegian Petroleum Society (NPF) Special Publication, 10: 145-174. 
Christensen, O.B. 1962. Ostracodtyper fra Keuper-Rhaet lagserien i dybdeboringerne ved Harte og Ullerslev. Meddelelser fra Dansk Geologisk Forening, Kobenhavn, Geologisk Forening, 15(1): 90-98.

Cui, Wei-xia, Zeng, Guang-yan, Zhu, Hong-wei \& Li, Wen-ben. 2004. Early Jurassic megaspores and palynomorphs from the Bohu Depression, Yanqi Basin, Xinjiang, NW China. Acta Micropalaeontologica Sinica, 21: 292-308. [In Chinese, English summary.]

Dalland, A., Worsley, D. \& Ofstad, K. 1988. A lithostratigraphic scheme for the Mesozoic and Cenozoic succession offshore mid- and northern Norway. Norwegian Petroleum Directorate, Bulletin, 4: $65 \mathrm{pp}$.

Dettmann, M.E. 1961. Lower Mesozoic megaspores from Tasmania and South Australia. Micropaleontology, 7: 71-86.

Erdtman, G. 1947. Suggestions for the classification of fossil and recent pollen grains and spores. Svensk Botanisk Tidskrift, 41: 104-114.

Gry, H. 1969. Megaspores from the Jurassic of the island of Bornholm, Denmark. Meddelelser fra Dansk Geologisk Forening, Kobenhavn, 19: 69-89.

Harris, T.M. 1935. The fossil flora of Scoresby Sound East Greenland. Part 4: Ginkgoales, Coniferales, Lycopodiales and isolated fructifications. Meddelelser om Grønland, 112(1): $176 \mathrm{pp}$.

Harris, T.M. 1961. The Yorkshire Jurassic flora I. ThallophytaPteridophyta. British Museum (Natural History), London, 212 pp.

Jung, W. 1958. Zur Biologie und Morphologie einiger disperser Megasporen, vergleichbar mit solchen von Lycostrobus scotti, aus dem Rhät-Lias Frankens. Geologische Blätter für Nordost-Bayern, 8: 114 130 .

Jung, W. 1960. Die dispersen Megasporen der fränkischen Rhät-LiasGrenzschichten. Palaeontographica, B, 107: 127-170, 4 Pls.

Jux, U. \& Kempf, E.K. 1971. Microstructures of the Mesozoic megaspore Tasmanitriletes n.g. Grana, 11: 95-100.

Koppelhus, E.B. \& Batten, D.J. 1992. Megaspore assemblages from the Jurassic and lowermost Cretaceous of Bornholm, Denmark. Danmarks Geologiske Undersogelse, Serie A, 32: 81 pp.

Kovach, W.L. \& Batten, D.J. 1989. World-wide stratigraphic occurrences of Mesozoic and Tertiary megaspores. Palynology, 13: 247-277.

Li, Wen-ben. 1993. Kuqaia - a new palynomorph taxon. Acta Micropaleontologica Sinica, 10: 71-76.

Lund, J.J. 1977. Rhaetic to lower Liassic palynology of the onshore south-eastern North Sea Basin. Danmarks Geologiske Undersøgelse, Rakke, II, 109: 1-129.

Lundblad, B. 1956. On the stratigraphical value of the megaspores of Lycostrobus scotti. Sveriges Geologiska Undersökning, Series C (547), Arsbok, 50: 1-11.

Marcinkiewicz, T. 1960. Analiza megasporowa osadów jurajskich okolic Gorzowa Śląskiego - Praszki. Kwartalnik Geologiczny, 4: 713-733. [Russian and English summaries.]
Marcinkiewicz, T. 1962. Megaspory retyku i liasu z wiercenia Mechowo koło Kamienia Pomorskiego i ich wartość stratygraficzna. Instytut Geologiczny, Prace, 30: 469-493. [Russian and English summaries.]

Marcinkiewicz, T. 1969. Granica między retykiem i liasem w Polsce pozakarpackiej na podstawie badań florystycznych. Kwartalnik Geologiczny, 13: 100-114. [Russian and English summaries.]

Marcinkiewicz, T. 1971. Stratygrafia retyku i liasu w Polsce na podstawie badań megasporowych. Instytut Geologiczny Prace, 65: 58 pp. [Russian and English summaries.]

Marcinkiewicz, T. 1981. Megaspory [Jura Dolna, Flora]. In: Malinowski, L., Bielecka, W. \& Rogalska, M. (Eds), Budowa geologiczna Polski, Atlas skamieniałości przewodnich i charakterystycznych, Mezozoik, Jura. Wydawnictwa Geologiczne, Warszawa, 3(2b) (for 1980): 79-97.

Pedersen, T., Harms, J.C., Harris, N.B., Mitchell, R.W. \& Tooby, K.M. 1989. The role of correlation in generating the Heidrun Field geological model. In: Collinson, J.D. (Ed.), Correlation in hydrocarbon exploration, 327-338. Graham \& Trotman, London, and Norwegian Petroleum Society, Oslo.

Potonié, R. 1956. Synopsis der Gattungen der Sporae dispersae I. Teil: Sporites. Beihefte zum Geologischen Jahrbuch, 23: 103 pp.

Potonié, R. 1958. Synopsis der Gattungen der Sporae dispersae, II. Teil: Sporites (Nachtrage), Saccites, Aletes. Praecolpates, Polyplicates, Monocolpates. Beihefte zum Geologischen Jahrbuch, 31: 114 pp.

Potonié, R. 1960. Synopsis der Gattungen der Sporae dispersae, III. Teil: Nachtrage Sporites, Fortsetzung Pollenites mit Generalregister zu Teil I-III. Beihefte zum Geologischen Jahrbuch, 39: 189 pp.

Reinhardt, P. 1963. Megasporen aus dem Keuper Thüringens. Freiberger Forschungshefte, C164: 115-128.

Simon, W. \& Bartenstein, H. (Eds). 1962. Leitfossilien der Mikropalaontologie. Borntraeger, Berlin, $432 \mathrm{pp}$.

van der Hammen, T. 1955. Principios para la nomenclatura palinológica sistematica. Boletin Geologico, 2(2) (for 1954): 3-21.

Wicher, C.A. 1957. Die mikropaläontologische Gliederung des nichtmarinen Keuper. Erdöl und Kohle, 10: 3-7.

Wierer, J.F. 1997. Vergleichende Untersuchungen an Megasporenvergesellschaftung der alpinen und germanischen Mittel- und Obertrias. Münchner Geowissenschaftliche Abhandlungen, A, Geologie und Paläontologie, 35: 1-175.

Will, H.J. 1969. Untersuchungen zur Stratigraphie und Genese des Oberkeupers in Nordwestdeutschland. Beihefte zum Geologischen Jahrbuch, 54: 240 pp.

Ziegler, W.H. 1990. Geological atlas of Western and Central Europe 1990. Shell Internationale Petroleum Maatschappij B.V., Den Haag, $239 \mathrm{pp}$. 